\title{
The Financial Lives of Families. How Credit Regimes and Welfare States Shape Household Indebtedness
}

\author{
Andreas Wiedemann* \\ Nuffield College, University of Oxford
}

Draft version: July 24, 2019

\begin{abstract}
Debt has become an essential part of many families' daily lives. Yet we know little about the cross-national dimension of credit markets as a substitute for welfare states. I argue that the interaction of welfare states and credit regimes constrains the ways in which households cope with financial shortfalls, thereby producing and reproducing patterns of indebtedness. I first show that when welfare states are weak and credit regimes permissive, households tap into credit markets as a private coping mechanism. In restrictive regimes, households draw on savings and cut expenditures. I then turn to event studies and difference-in-differences designs based on full-population administrative data from Denmark and panel data in the U.S., to document how variation in welfare state coverage and credit access explains variation in debt burdens across income groups. The findings expand recent work in comparative political economy on the links between financial markets and welfare states, shedding light on the role of credit regimes and social policies as drivers behind indebtedness and its socio-economic and distributional consequences.
\end{abstract}

*Postdoctoral Prize Research Fellow. Email: andreas.wiedemann@nuffield.ox.ac.uk 


\section{Introduction}

Many families these days are no strangers to debt. Whether they borrow money to obtain a home, to go to university, or to smooth income losses during unemployment, households devote increasingly large shares of their incomes to repay various forms of debt. Across the OECD, household debt as a share of disposable income has grown from an average of $78 \%$ in 1995 to $134 \%$ in 2015. ${ }^{1}$ Aggregate statistics, however, mask considerable variation between countries that have experienced high growth in household debt over the past decades such as Denmark, the U.S., and the Netherlands and countries where debt levels are much smaller and stagnant such as Germany and Japan.

In this paper, I offer a new perspective on the ways in which financial markets shape political economies and reach into people's daily lives. I argue that growing indebtedness is the downstream consequence of changes in labor markets, life course trajectories, and welfare states that expose households to financial shortfalls. ${ }^{2}$ Despite the magnitude and importance of household debt, however, we know little about the ways in which credit markets interact with welfare states and, in particular, how this plays our cross-nationally. Credit markets are rarely seen as part of the welfare regime, nor does work on financial markets integrate social policies in their analyses. But to understand the growing influence of credit markets and explain differential levels of indebtedness across and within countries, we have to see credit markets as integral parts of our political economy in general and of welfare regimes in particular.

Prior work has studied growing household indebtedness from a variety of angles. One body of work suggests that citizens borrow money to maintain their living standards in light of growing levels of inequality (Frank 2010; Kumhof, Rancière and Winant 2015), wage stagnation (Rajan 2010; Stiglitz 2015), and limited fiscal redistribution. In the U.S., more people use credit markets as a safety net by borrowing money during times of hardship (Montgomerie 2013; Morduch and Schneider 2017). For policymakers, credit markets offer a way to deal with growing societal demands and democratic overload in light of limited fiscal capacity that is off the budget and easier to achieve than politically contested fiscal redistribution (Krippner 2011; McCarty, Poole and Rosenthal 2013). Deficit spending has been replaced by a model of "privatized Keynesianism" that rests on the expansion of private instead of public debt (Crouch 2009), suggesting that credit markets can substitute for

\footnotetext{
${ }^{1}$ OECD National Accounts Statistics. 2018

${ }^{2}$ The concept of life course trajectories captures individuals' movement between different life-stages, from raising children, education and training, employment, and retirement (cf. Mayer 2009).
} 
welfare states and offer a private insurance against risks by providing access to credit and even against old age by promoting homeownership and housing wealth as a nest egg (Ansell 2014; Conley and Gifford 2006; Prasad 2012; Schwartz 2008). Ahlquist and Ansell (2017) identify a partisan link between inequality and demand for credit, where left-wing governments resort to fiscal redistribution whereas right-wing governments replace welfare spending with policies that improve credit availability.

These accounts highlight the role of credit markets as providers of liquidity to help people smooth income losses, but their focus on issues around inequality and the emphasis on the Anglo-Saxon world often obscures and ultimately fails to explain considerable variation in debt levels across and within countries. Why do countries like Denmark and the Netherlands with lower levels of income inequality have similar or even higher levels of debt compared to more unequal countries such as the U.S. or the U.K.? Why did debt levels in Germany not increase to compensate for stagnating and even declining wages during the 1990s and early 2000s (DIW 2009). These differences can also not be explained by partisan accounts as financial liberalization and deregulation in most OECD countries were supported by parties across the political spectrum. The comparative political economy frameworks such as varieties of capitalism (Hall and Soskice 2001) or typologies of welfare regimes (EspingAndersen 1990, 1999) remain largely silent about household indebtedness. Nor do empirical patterns of debt levels across countries match the theories' conceptual country-clusters, as Figure 1 shows. The few studies that incorporate a comparative perspective largely focus on national-level aggregate data that mask important variation the distribution and types of debt that different groups in society hold. These shortcomings then pose two main questions. What explains variation in household debt across and within countries? And under what circumstances can credit markets offer a private alternative to public social policies?

In this paper, I introduce a "social policy theory of everyday borrowing," arguing that the interaction of two factors, the structure of welfare states and resulting financial shortfalls as well as the structure of credit regimes, produces and reproduces patterns of indebtedness that reflect how individuals address the financial consequences of labor markets risks. The first factor is the size of households' financial shortfalls that arise between, on the one hand, income losses caused by fragmented and disrupted employment patterns and, on the other hand, weaker and incomplete social policy support due to welfare state retrenchment and policy drift (Hacker 2008; Hemerijck 2013). Households increasingly turn to private coping mechanisms to address these financial shortfalls and draw on savings or cut consumption or, alternatively, go into debt and borrow money. 
Figure 1: Changes in Total Household Debt-to-GDP Ratios Across OECD Countries

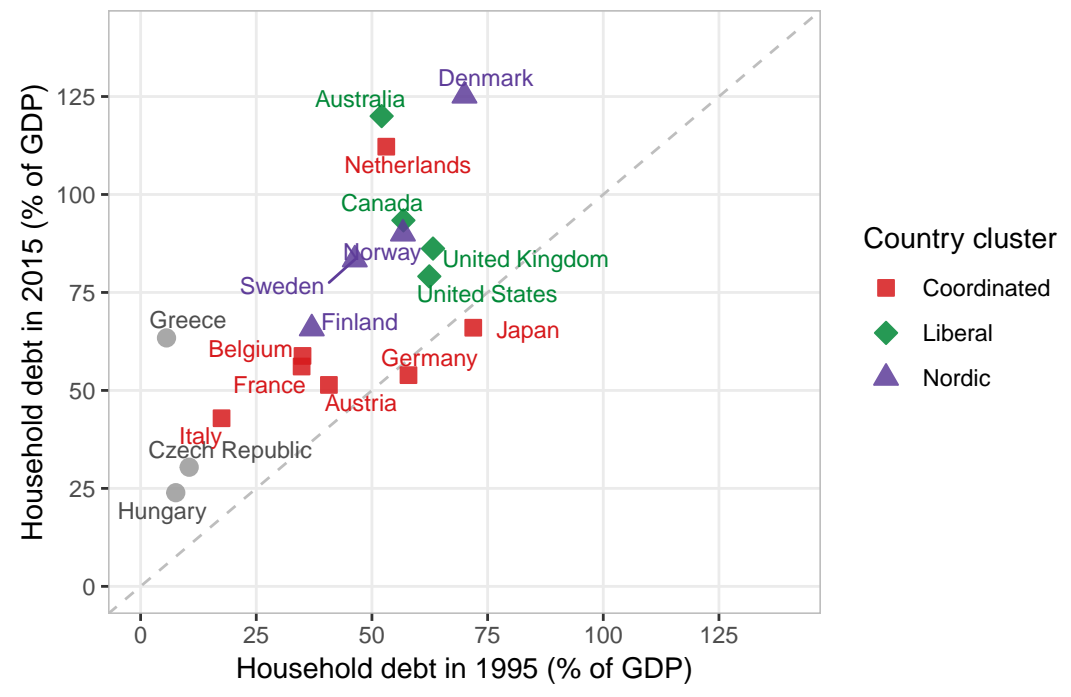

Notes: Debt is measured as total credit to households. Color codes indicate common political economy typologies of liberal market economies, conservative coordinated market economies, and Nordic Social-democratic economies based on Esping-Andersen (1999). Source: OECD National Accounts Statistics 2018.

The second factor is the structure of what I call a country's credit regime. This concept describes the institutional and political environment that shapes the breadth and depth of financial markets, the allocation of credit between businesses and households, and regulatory and fiscal borrowing incentives. These factors jointly influence who gets credit in the economy and how easily individuals can tap into credit markets and borrow money to address financial shortfalls. Permissive credit regimes combine open financial markets with large pools of capital that tend to be allocated disproportionately toward households, thus making credit easily available to households. Restrictive credit regimes limit capital inflows, have smaller capital markets, and direct credit flows toward the business sector. These regimes limit access to credit for households and, instead, incentivize households to save. The upshot of this argument is that when welfare states comprehensively address labor market risks, individuals do not have to borrow because financial shortfalls are small. However, when incomplete social policies lead to larger financial shortfalls, the structure of credit markets determines if households cut expenses, draw on savings, or borrow money. Since welfare state coverage affects individuals differently, we should see differences in the distribution of debt accordingly.

To test the implications of my theory, I first develop a novel empirical measure of credit regime permissiveness, demonstrating considerable variation in permissiveness across coun- 
tries that correlates with financial development and household debt levels. I then use three empirical tests to document how credit regimes and welfare states interact to produce patterns of indebtedness. My social policy theory of everyday borrowing applies to different social policy domains and type of financial shortfalls, but for reasons of space, I only focus on income loss during unemployment. First, I use cross-national survey data to show that in countries with permissive credit regimes such as Sweden and the U.K., households are more likely to go into debt to address unexpected income losses than in restrictive regimes such as Germany or Italy. Second, I demonstrate that the negative relationship between welfare state generosity and household debt only emerges in cases of permissive credit regimes, confirming these micro-level patterns. Finally, I turn to Denmark and the U.S. as two cases with permissive credit regimes and flexible labor markets but markedly different welfare regimes. Drawing on full-population administrative data in Denmark and panel data in the U.S., I use event studies and a generalized difference-in-differences design to show that within each country, households that are least protected by the welfare state borrow the most. In Denmark, borrowing is concentrated among middle- and higher income groups because lower-income groups are well protected by the welfare state. In the U.S., by contrast, borrowing stretches across the income spectrum but is more prevalent among lower-income individuals who are financially more vulnerable.

This paper contributes to recent work in comparative political economy in theoretical and empirical ways. It develops a theoretical framework that integrates literatures on financialization and credit markets with work on social policies in the study of comparative political economy, highlighting how the interaction of welfare states and credit regimes helps us understand variation in debt levels. It expands recent, largely U.S.-focused work on the links between financial markets and welfare states (Ahlquist and Ansell 2017; Montgomerie 2013; Prasad 2012; Thurston 2018) by focusing on the welfare states (or the lack thereof) as a key driver of indebtedness from a comparative perspective. ${ }^{3}$ Moreover, it introduces the concept of credit regimes to current models of comparative political economy (Baccaro and Pontusson 2016; Hall and Soskice 2001) and comparative social policy (Esping-Andersen 1999; Hemerijck 2013) to explain the role of debt as a coping strategy to deal with shifting social risks (Hacker 2008). The findings suggest that seeing the relationship between credit markets and welfare states as a trade-off is misleading. Credit markets do not fulfill the same functions as social policies because they differ in the allocation of risks, resource flows, and access and eligibility rules. The comparison between the U.S. and Denmark shows that

\footnotetext{
${ }^{3}$ For an important comparative perspective on Germany see Mertens (2017).
} 
credit markets can substitute for social policies in their absence but also be layered on top of existing welfare states, serving different groups. Empirically, this paper goes beyond aggregate data predominately used in prior work combines macro- and micro-level evidence to study the links between credit regimes and welfare states not only across countries but also across households in the domain of unemployment risk.

The findings of this paper help us understand the drivers behind indebtedness and shed light on welfare states' mediating role. This is important because indebtedness is associated with consequential socio-economic consequences, ranging from severe economic downturns (Mian and Sufi 2014) and financial crises (Schularick and Taylor 2012) to rising wealth and income inequality (Kumhof, Rancière and Winant 2015), heightened economic insecurity (Porter 2012; Warren and Tyagi 2003), and negative health outcomes (Turunen and Hiilamo 2014) and employment prospects (Kiviat 2017).

\section{A Social Policy Theory of Everyday Borrowing}

It may seem surprising to think that credit markets can fulfill functions that are similar to social policies, not least because welfare states were in part designed to alleviate negative consequences of market vagaries. Welfare states, first, distribute resources across individuals, typically from high-income to low-income groups, through poverty relief, subsistence support, and redistributive policies aiming to reduce income inequality. Second, they provide insurance against the financial impact of social risks and allow individuals to smooth consumption during unemployment, sickness, and old age. While social insurance policies have redistributive elements that lower income inequality, they are fundamentally about the redistribution across risk and income groups (Baldwin 1990; Rehm, Hacker and Schlesinger 2012). Third, welfare states promote social opportunity and offer in-cash or in-kind support during the life course through social investment in education, childcare, or paid parental leave programs. In contrast to welfare states' redistributive function, which transfers resources across individuals, the latter two insurance and investment functions redistribute resources over the life cycle (Barr 2001).

Credit markets mirror welfare states' functions in three crucial ways. First, credit markets also redistribute resources - although not across individuals but through time, moving resources from the borrower's future self into the present. Second, credit markets provide financial liquidity through credit cards, bank loans, payday loans, or home equity loans that allow individuals to address financial shortfalls or to meet unexpected expenditures. How- 
ever, in contrast to welfare states that "socialize" risks and, in Esping-Andersen's (1990) words, "de-commodify" individuals, credit markets privatize risks as the borrower has to repay her loan with interest and, therefore, "re-commodify" individuals by making them even more dependent on market participation as debt repayment requires stable, long-term future income streams. Third, credit markets enable individuals to invest in human capital such as education financed through student loans as well as financial assets such taking out a mortgage to buy a home. ${ }^{4}$ Traditionally a place of shelter, homeownership has recently turned into a form of investment and path to building wealth, a nest-egg during retirement, and an additional source of credit through home equity loans based on the value of the underlying property (Castles 1998; Schwartz and Seabrooke 2009).

Credit markets are not the only option to privately cope with income losses. Individuals can draw on savings, cut expenditures, or sell their home and move to a cheaper place. These options, however, are often unavailable. The life-cycle theory of savings assumes that individuals smooth consumption over their lifetime and save and consume accordingly (Browning and Crossley 2001). In practice, however, most individuals accumulate little savings, either because of financial illiteracy (Lusardi 2008), because they are myopic and underestimate risk (Benartzi and Thaler 1995), or because they lack self-control or are too impatient to put aside savings (Ameriks, Caplin and Leahy 2003; Gathergood 2012). Cutting expenses, by contrast, presumes that individuals have financial space to cut. Often, this is not the case because people live paycheck-to-paycheck and have little financial room to maneuver (Kaplan, Violante and Weidner 2014; Morduch and Schneider 2017). Since moving is financially and emotionally costly, borrowing money can be a viable alternative if income losses are expected to be only temporary.

In this paper, I focus on credit market's liquidity function to help people address financial shortfalls. I argue that the rise in household indebtedness is the downstream consequence of changes in labor markets, life course trajectories, and welfare states that, together, lead to financial shortfalls. The variation in household debt across and within countries is driven by the ways in which two factors interact: first, the structure of the welfare state and the resulting financial shortfalls and, second, the structure of a country's credit regime interact.

\subsection{Financial Shortfalls and the Degree of Welfare State Support}

The first factor factor that drives demand for credit are the financial shortfalls that arise between, on the one hand, the financial consequences of increasingly fragmented and dis-

\footnotetext{
${ }^{4}$ On investment in human capital as personal asset see Becker (1976).
} 
rupted employment patterns and, on the other hand, incomplete social policy support due to welfare state retrenchment and policy drift. The transition of Fordist economies into flexible knowledge economies have affected labor markets, life course trajectories, and welfare states and left deep marks on households' financial lives. The rise of non-standard forms of employment, increasingly "fissured" workplaces (Weil 2014), and more frequent spells of unemployment disrupted employment patterns and made incomes more volatile (Emmenegger et al. 2012; Schmid 2002).

Welfare states, however, are increasingly at odds with households' changing employment patterns and life course trajectories. Social insurance policies that address unemployment or sickness have come under economic and fiscal pressure due to rising levels of unemployment, growing demands from recipients, cost-cutting strategies of employers, as well as partisan politics and ideology. ${ }^{5}$ Policy responses range from outright retrenchment and tighter eligibility rules to less visible but equally consequential forms of policy drift where existing policies are not updated to meet changing realities (Hacker 2004; Thelen 2004).

Financial shortfalls, therefore, arise when income losses are incompletely or not at all addressed by social policies. This shifts the financial consequences of labor market risks, as Jacob Hacker (2008) has argued, away from society onto individuals themselves, and increases demand for private coping mechanisms such as savings or credit. These trends pose a big question: how do households address financial shortfalls that arise between weaker and incomplete social policy support on the one hand and income losses driven by fragmented and disrupted employment patterns on the other? In these cases, households have to draw on private alternatives, either savings or reduce expenses, or borrowing. Whether households tap into credit markets and borrow money to address financial shortfalls depends on the structure of a second factor that I call credit regime.

\subsection{The Growing Influence of Credit Regimes}

The second factor - the structure of a country's credit regime - influences the degree to which households are able to borrow money to address financial shortfalls. I conceptualize credit regimes as the institutional and policy configurations that shape the size of the pool of credit and capital, the degrees to which credit is allocated toward households or businesses, and regulatory and fiscal borrowing incentives.

Scholars have long recognized that there are important cross-national differences in the structure of national financial markets, including bank-based and market-based systems

\footnotetext{
${ }^{5}$ See Allan and Scruggs (2004); Hemerijck (2013); Huber and Stephens (2001); Pierson (2001).
} 
(Allen and Gale 2000; Zysman 1983), differences in legal traditions and the strength of protection of shareholder rights and minority investors (La Porta, Lopez-De-Silanes and Shleifer 1999), and the structure of corporate governance systems (Culpepper 2005). Recent work has shifted attention toward household debt, focusing on the structure of mortgage markets and the degrees to which OECD countries deviate from the U.S. ideal-type model with high ownership rates, high levels of securitized mortgage debt, and low transaction costs (Schwartz 2008). Moving beyond housing markets, Fuller (2015) has introduced a nuanced perspective and identified a set of regulatory and fiscal policies that shape degrees of "credit encouragement" and "credit mitigation." These accounts and their emerging household perspective on credit market are an important first step that helps us understand why households are more indebted in some countries than in others. Yet they fall short on developing a theoretical and empirically testable concept of cross-national variation in credit regimes. First, existing work tends to focus either on differences in mortgage markets or corporate governance regimes, thus assuming that each sphere is independent of the other. Second, they emphasize country typologies and "national models" when the institutional and policy configurations of credit regime may be more fluid. As Krippner (2011) points out, policy outcomes in the domain of credit markets are more often the results of unintended consequences than deliberate choices. Lastly and most importantly, we lack empirical measures of the different facets of countries' credit markets that jointly determine the degrees to which households can tap into credit markets.

I build on these political economy models of financial market structures and propose an analytical framework of credit regimes that consist of three dimensions that jointly influence the permissiveness of a country's credit regime. The first dimension is about factors that shape the size of the pool of capital that can be allocated toward households and businesses. Institutional investors such as pension funds and insurance companies have emerged as important drivers behind the expansion of financial markets, aided by the shift from defined-benefit to defined-contribution pension plans and the broader privatization and marketization of pensions systems and (Fligstein and Goldstein 2015; Hassel, Naczyk and Wiß 2019; Häusermann 2010). The funding needs of firms is another factor that influences the size of the domestic capital pool. If firms can rely on market-based external funding options such as equity and bond markets, banks have more capital at their disposal that they can lend to other actors such as households. By contrast, when firms draw more on bank loans to finance investment, equity and bond markets are less important and tend to be underdeveloped (Goyer 2006). 
The second dimension captures factors that influence the allocation of this pool of capital between households and businesses. A core driver of credit flows in the economy are the institutional relationships between banks and the business sector as well as between banks and households. Firms' corporate governance structures and their funding needs strongly shape these relationships. In countries where non-market relationships and relational contracting are the norm and ownership of firms is concentrated, banks develop close ties with firms to fund their business activities and operate as a firm's "house bank" by providing long-term, patient capital (Hall and Soskice 2001; Streeck and Yamamura 2001). Since strong lending ties between banks and businesses push credit flows toward firms, capital markets for mortgages and pension assets are weakly developed (Engelen and Konings 2010). By contrast, in countries with hierarchical and competitive market arrangements, formal contracting, and dispersed firm ownership structures, close relationships and cross-holdings between banks and businesses are rare. Instead, arm's length financial markets underpin corporate governance models and satisfy firms' funding requirements. Equity and bond markets and other types of non-bank investors provide sufficient capital and crowd out banks as dominant business lenders. Banks seek out households as sources of potential borrowers and develop closer relationships with them.

The third dimension is about the regulatory and fiscal policies that create, promote, and sustain these links and shape incentives for households to borrow. Governments can incentivize banks to lend to households by regulating loan volumes and credit risks through collateral requirements, loan-to-value ratios, rules about securitization practices, and the types of financial products available. Governments can also incentivize households to borrow through tax provisions that give preferential tax treatment to mortgages and related interest payments, often as part of a broader government intervention to encourage homeownership. These policy choices not only promote credit flows toward households but can also reduce savings rates because households can tap into credit markets more easily (Jappelli and Pagano 1994). Together, the size of the pool of capital, the allocation of credit toward households and businesses, and the regulatory and fiscal policies that incentivize or repress borrowing jointly shape the permissiveness of credit regimes and the ease with which households can borrow money to address social policy-related financial shortfalls. 


\subsection{An Institutional Perspective on the Role of Credit to Address Financial Shortfalls}

The ways in which the structure of welfare states interact with the structure of credit regimes determine how households cope with the financial consequences of changing labor markets: publicly through the welfare state or privately through either savings and cuts in expenditures or borrowing money. This means that groups who are well-covered and financially supported by the welfare state do not have to draw on credit markets and borrow money because social policy-related financial shortfalls are small. However, for groups where social policy coverage and financial support are weak, the structure of the credit regime strongly shapes which private coping mechanisms are available. Figure 2a illustrates this logic from a households' perspective. In restrictive regimes, households have limited access to credit markets and are forced to rely on savings or expenditure cuts. In permissive regimes, households have easy access to credit markets and borrow money to address financial shortfalls. Cross-nationally, the interaction of welfare states and credit regimes influences what coping mechanisms prevail in each country, leading to institutional arrangements that vary across countries as indicated in Figure 2b. Countries can fall anywhere within the space circumscribed by the triangle, indicating different combinations of coping mechanisms. Credit regimes are the key determinant that shift countries either toward borrowing or toward savings and expenditure cuts. We can therefore think of the sides of the triangle as representing three different models: one model in which credit markets substitute for limited or nonexisting welfare states. Another model in which credit markets are layered on top of existing welfare states, thus complementing social policies. And, finally, a third model in which credit markets are suppressed and households rely on a combination of welfare state support and private savings or cuts in expenses.

\section{Credit as Substitute: Combining Credit Markets with Savings and Expenditure Cuts}

In countries with limited welfare states and permissive credit regimes, individuals rely heavily on private resources to address social policy-related financial shortfalls. Households heavily use credit cards and other types of loans to smooth income losses during unemployment and to meet unexpected expenses. Savings rates are low, in large part because credit markets are easily accessible. With tax-incentivized mortgages, they purchase homes that not only provide shelter but also home-equity lines of credit, a private nest-egg for retirement, and access to locations with good schools and jobs. The welfare state provides weak protection 
Figure 2: Coping with Financial Shortfalls

(a) Micro Perspective: How Households Cope with Financial Shortfalls

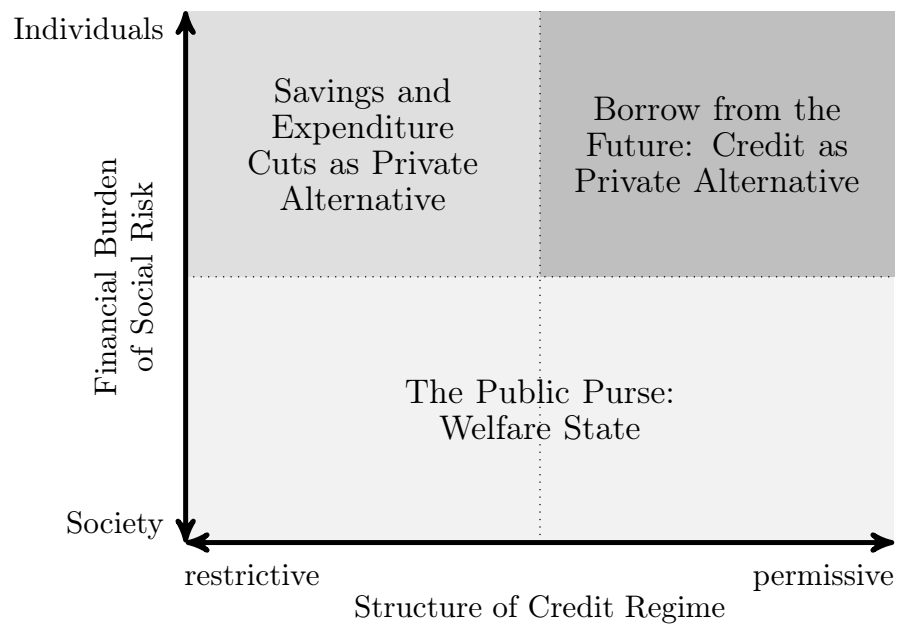

(b) Macro Perspective: Country-Level Mix of Coping Mechanisms

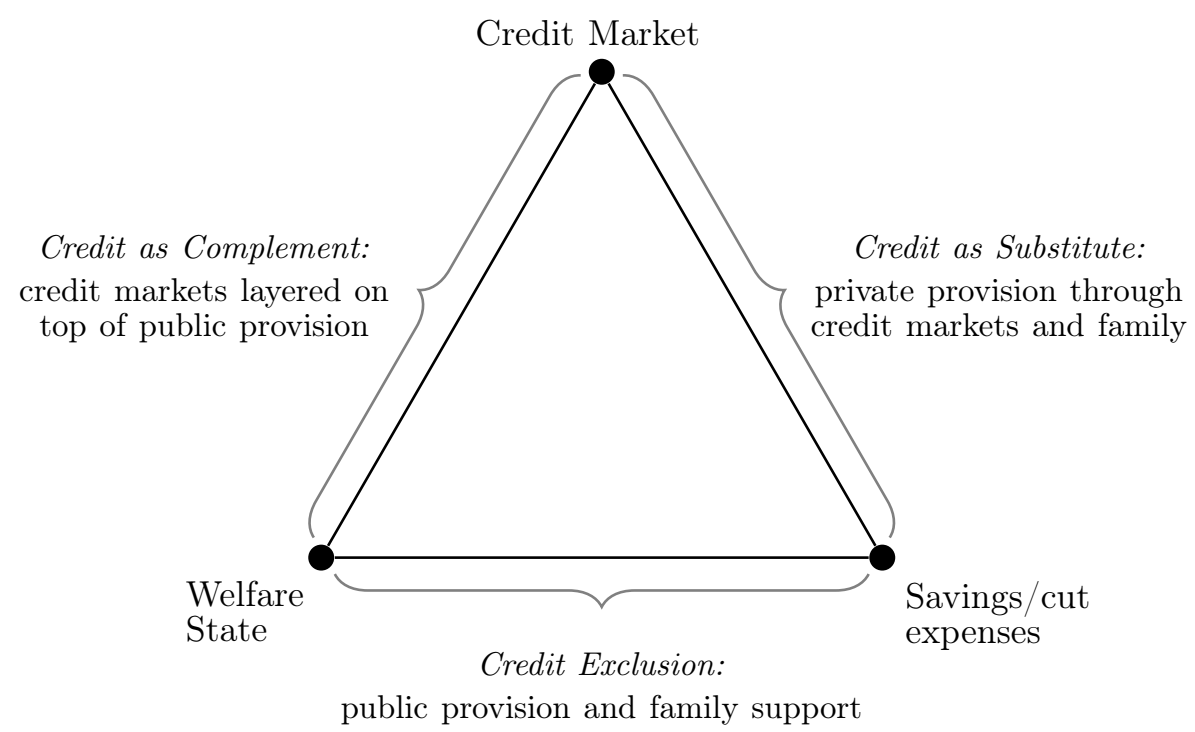

against labor market risks. Individuals across the income spectrum draw on credit markets, but the types of debt they use are heavily stratified. Lower-income and less wealthy groups are more likely to draw on what I call consumption debt that allows them to maintain their living current status, while higher-income and more wealth groups tend to rely on investment debt that promotes social opportunity through housing and education. This raises the opportunity costs for lower-income individuals because there is no financial cushion 
that offers a safety net to allow everyone to make debt repayment even in times of financial distress.

\section{Credit as Complement: Combining Credit Markets with Welfare States}

In countries with comprehensive but stratified welfare states and permissive credit regimes, social policies address labor market risks in divided and stratified ways, often by income or labor market status. Here a permissive credit regime is layered on top of existing welfare states and complements social policies for segments of society that are incompletely covered by the welfare state, for example when unemployment benefits are generous and comprehensive for low-income groups but more limited for higher-income groups. This results in a diverging use of credit markets. Low-income groups rely heavily on generous financial support from the welfare state, whereas high-income groups tap into credit markets to complement less-generous support from the welfare state. Unlike in the previous model, credit markets only come into play for those segments of society that receive weak financial support from the welfare state - a very different group compared to the case of a full substitute, where low-income individuals borrow to much greater degrees.

\section{Suppressed Credit: Combining Welfare States with Savings and Expenditure Cuts}

In the final model, the welfare state protects and supports but also stratifies individuals, not necessarily by income but also by labor market status. It offers comprehensive protection and income support for individuals working in the core of the economy but only limited protection for those marginally employed on the periphery. In contrast to the other two models where different societal groups go into debt and borrow money to address financial shortfalls due to disrupted employment patterns and life course choices, this model combines the segmented welfare state with a restrictive credit regime that limits individuals' access

to credit and, instead, incentivizes savings and other private, often family-based coping mechanisms. Credit markets play no social policy function. Households that receive limited support from the welfare state and face financial shortfalls have to draw on alternative private coping mechanisms such as savings, expenditure cuts, or family support. 


\section{Mapping the Comparative Landscape of Credit Regimes}

The structure of credit regimes and their degree of permissiveness set the boundary conditions if and when households go into debt and borrow money to address financial shortfalls. In this section, I identify a set of six indicators that map onto the three main dimensions of credit regimes that I introduced in section 2.2 above: the size of the pool of capital, the allocation of capital and credit between households and firms, and regulatory and fiscal policy incentives to borrow. I then derive country-specific credit regime permissiveness scores using principal component analysis - a dimension-reduction technique that projects high-dimensional data onto a low-dimensional space. The resulting principal components reflect the underlying structure of the data while capturing the directions of the data space with the most variance.

\subsection{A New Measure of Credit Regime Permissiveness}

I collect data for six empirical indicators along the three key credit regime dimensions. The final sample contains seventeen North American and Western European countries for which measures are available. A comprehensive list of all six indicators and their data sources as well as the distribution of these indicators across countries appear in Table A.1 and Figure A.1 in the online appendix.

\section{Breadth and Depth of Financial Markets}

The first dimension is about factors that shape the size of the pool of capital that can be channeled toward either households or businesses. This is an important dimension because it reflects how well financial markets are developed, what role institutional investments such as pension funds or insurance companies play as drivers of financialization, and to what extent households themselves are active participants in these market. The first measure I use is the stock market capitalization as a share of GDP from the World Bank Global Financial Development Database, which reflects the size and prevalence of publicly-traded firms and the liquidity of equity markets. This indicator reflects how firms meet their funding needs as well as potential investment opportunities for households and institutional investors. Second, I measure the overall size of private and public pension assets in capitalized pension funds using the size of pension assets as a share of GDP from the OECD Global Pension Statistics. This measures the influence of institutional investors, in this case pension funds, 
whose investment needs not only drive financialization but also influence the marketization of households' assets (Clark 2000). Both indicators gauge the breadth and depth of financial markets, thus capturing the availability of and demand for capital that lenders can distribute between households and businesses.

\section{Allocation of Capital and Credit between Households and Businesses}

The second dimension is about institutional and political factors that shape the allocation of capital and credit between households and businesses. I first use the amount of bank lending that goes toward the business sector, measured as a share of total lending to businesses and households. This indicator comes from Leon (2018). In corporate governance systems based on long-term funding through patient capital, banks are more likely to lend to the business sector than to households, whereas in market-based systems, banks play a much smaller role in funding firms' activities and, instead, direct their lending toward the household sector. ${ }^{6}$ Second, I measure governments' influence over lending decisions and the portfolio composition of banks using the share of government-owned banks in the economy. This indicator comes from Barth, Levine and Caprio (2013). When governments want to promote economic policies such as export-led growth, political control over banks is a useful instrument to direct capital in line with overarching policy objectives. Recent work on growth models suggests that in consumption-driven models, politicians aim to facilitate easy access to credit, whereas in export-driven models, politicians seek to suppress consumer lending and direct funds toward the export-oriented sector (Baccaro and Pontusson 2016). Moreover, government ownership allows banks to deviate from a strictly profit-maximizing orientation and seek public investment instead, as is the case with savings banks such as Sparkassen in Germany or Cajas in Spain.

\section{Regulatory and Fiscal Incentives For Credit Formation in the Housing Market}

The final two indicators reflect regulatory and fiscal influence on credit formation in the housing market, which is an important element of domestic credit regimes whose design has broader downstream consequences on the provision of credit to households (see Schwartz and Seabrooke 2009). First, I use the average observable maximum loan-to-value ratio (LTV), which measures the value of mortgage debt relative to the value of the underlying asset. This indicator comes from Cerutti, Dagher and Dell'Ariccia (2017). LTV ratios of 100\%, common during the years leading up to the financial crisis in 2008, meant that lenders would finance

\footnotetext{
${ }^{6}$ For a sectoral composition of credit flows see Figure A.4 in the online appendix.
} 
the total value of the property without a downpayment. In part, this indicator is a measure of risk aversion as higher LTVs make lending riskier because the collateral lenders can seize in the event of default is small compared to the loaned amount. It is also an indirect measure of creditor, debtor, and regulators' willingness to accept higher levels of mortgage debt in the economy (see Fuller 2015, p. 254). Second, I complement the regulatory LTV indicator with a fiscal policy indicator of the tax relief on debt financing cost of homeownership. This indicator captures the gap between market interest rate and after tax debt financing cost due to tax deductibility of mortgage interest payments, limits on deductibility period and deductible amount, and availability of tax credits for loans. The indicator is zero for countries with no tax relief on debt financing costs for mortgages. This measure comes from Andrews, Caldera Sánchez and Johansson (2011).

Permissive credit regimes incentive credit formation in the housing market through low LTV ratios and fiscal incentives to take out mortgages. Low homeownership rates have downstream consequences that go beyond weaker demand for mortgages. Mortgage markets are smaller and weakly developed. Financial products that depend on liquid housing markets such as home equity loans are limited or non-existent, reducing the range of financial products an the ability to generate loans out of housing assets. Moreover, house prices tend to appreciate less because there are fewer investors and regular buyers who want to turn-over houses quickly to make financial gains.

\subsection{Credit Regime Permissiveness in OECD Countries}

Based on the six indicators described above, I create country-specific credit regime permissiveness scores using principal component analysis (PCA). Since not all indicators are available for every year, I first average each indicator over the period of 2000 to 2017. With PCA we can identify latent dimensions that jointly explain the variance of all the indicators. The first and second principal components account for over two-thirds of the variation across all countries in the sample, explaining $43.6 \%$ and $24.3 \%$ of the variation, respectively. I use a PCA model with one factor to derive the scores for countries' credit regime permissiveness and normalize them between -1 (most restrictive) and 1 (most permissive). ${ }^{7}$

Figure 3 shows how the countries in the sample rank based on the permissiveness of their credit regimes. The Netherlands and the U.S. have the most permissive credit regimes, whereas Italy and Germany have the most restrictive credit regimes. All other countries fall

\footnotetext{
${ }^{7}$ Factor loadings appear in Table A.2. Figure A.2 shows the distribution of countries along the first two principal components, together with the predictive power of each indicator.
} 
Figure 3: Credit Regime Permissiveness Scores Across OECD Countries

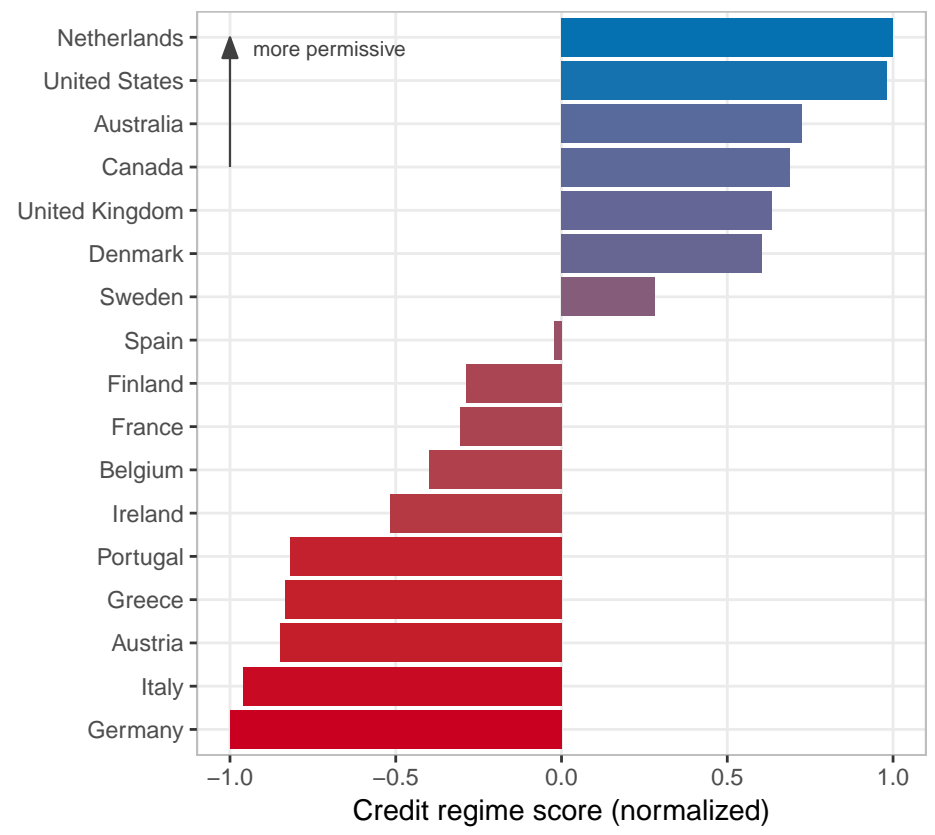

Notes: Scores are normalized, ranging between \pm 1 . Higher scores indicate a more permissive credit regime.

somewhere between the two extremes. Perhaps unsurprisingly, the Anglo-Saxon economies have more permissive regimes, but so do two Scandinavian countries, the Netherlands, Denmark and Sweden. Other countries with more restrictive credit regimes include Southern European countries as well as Germany and Austria.

Permissive credit regimes have two observable implications. Households should find it easier to tap into credit markets and borrow money and, consequently, overall household debt in the economy should be larger. The panels in Figure 4 confirm the predictive power of the credit regime scores. Figure 4 a shows a fairly strong relationship $\left(r=0.64^{* *}\right)$ between credit regime permissiveness and the IMF's financial development index, which captures access to and depth and efficiency of financial markets and financial institutions, suggesting a strong positive correlation between financial development and credit regime permissiveness. Figure $4 \mathrm{~b}$ plots the even stronger correlation between credit regime permissiveness and household debt, measured as a share of GDP $\left(r=0.72^{* * *}\right)$. Countries with more permissive credit regimes are associated with larger levels of indebtedness. 
Figure 4: Correlation between Credit Regime Permissiveness, Financial Development, and Household Debt

(a) IMF Financial Development Index

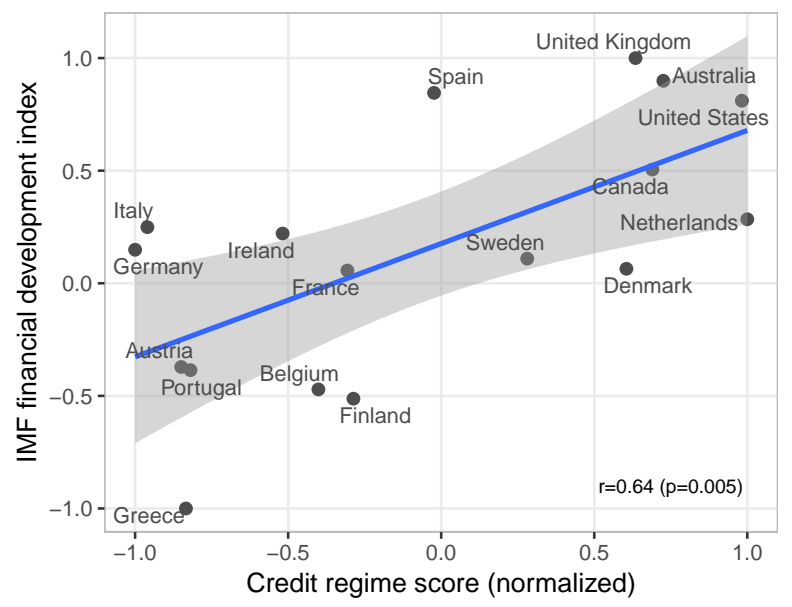

(b) Household Debt (\% GDP)

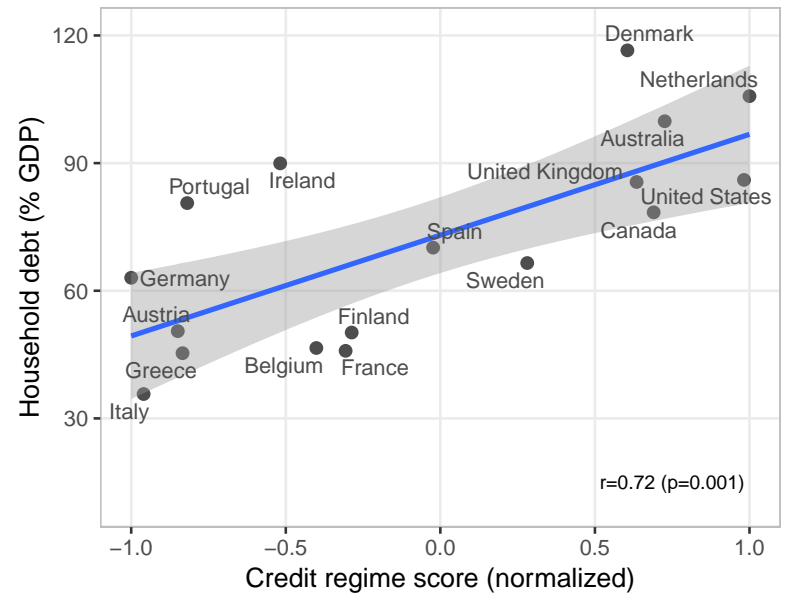

Notes: Panel (a): The IMF's Financial Development Index is a composite index capturing access to and depth and efficiency of financial markets and financial institutions. The index is normalized and ranges between -1 (least developed) to 1 (most developed). For methodological details on the construction of the index see Svirydzenka (2016). Panel (b): Household debt as a share of GDP comes from the BIS Total Credit Statistics (2016).

\section{Coping with Social Risks}

How do households cope with income losses, and what role does the structure of credit regimes play? In this section, I test the first empirical implications of my argument by studying how households cope with income losses from a comparative perspective. I then link the structure of credit regimes to the generosity of welfare states and provide empirical evidence under what circumstances credit markets emerge as alternatives to welfare states. The social policy theory of everyday borrowing applies to different social policy domains and types of financial shortfalls, but for reasons of space I only focus on labor market risks, specifically unemployment.

I begin by providing empirical support for the claim that there is considerable crossnational variation in households' coping mechanism in response to income losses before diving deeper into the structure of welfare states and credit regimes as institutional drivers of that variation. I use data from the second wave of the Life in Transition Survey (LITS II), conducted by the European Bank for Reconstruction and Development in 2010. The survey is based on a stratified random sample of 1,000 to 1,5000 adult respondents in five Western 
European countries as well as Eastern European and Central Asian countries. ${ }^{8}$ I only focus on the set of Western European countries. In the wake of the financial crisis, LITS asked respondents to indicate which coping mechanisms they or anyone else in their household drew on in the two years preceding the survey (i.e. 2008 and 2009). The options included reducing consumption, selling assets, delaying payments, and borrow money from banks as well as from family or friends. Respondents could select multiple coping strategies. This survey offers a unique setup to study cross-national differences in coping mechanisms.

I use the following mixed-effects logistic regression model to estimate whether respondents are more likely to cope with income losses by drawing on public benefits, cutting consumption, or borrowing from banks:

$$
Y_{i[c]}=\alpha_{c}+\mathbf{X}_{i t}^{\prime} \gamma+\epsilon_{i[c]}
$$

This is an adequate modeling strategy since we have individuals nested within countries, thus allowing me to estimate the overall country-specific probability of using a specific coping mechanism given individual-level characteristics. For each coping strategy, I estimate a separate model that includes income, employment status, education levels, marital status, gender, age, number of children in the households, and being a homeowner as fixed effects as well as random intercepts for countries. Figure 5 shows the odds ratios for the countryspecific random intercepts, taking into account respondents' socio-economic characteristics. In countries with more permissive credit regimes such as Sweden and the U.K., households are much more likely to borrow money from a bank to address economic difficulties and income losses, compared to restrictive regimes in Germany and Italy. Government transfers play the largest role in Sweden and Germany and the smallest in Italy, whereas cuts in expenditures are most likely in Italy and France and least likely in Sweden. This maps onto the three coping models introduced in section 2.3: the Nordics, exemplified by Sweden, combine public benefits and private credit markets; Germany combines public benefits, savings, and cuts in expenditures; and a hybrid case between both worlds in the Anglo-Saxon economies, indicated by the U.K.

What then explains this cross-national variation in coping mechanisms? Why are people in some countries much more likely to borrow money to address income losses, whereas in others people tend to draw more on savings or cut consumption? A key reason why borrowing is a more prevalent coping strategy in some countries but not in others lies in the structure of a country's credit regime. Only in cases where credit regimes are permissive and allow

\footnotetext{
${ }^{8}$ For more details see Sanfey (2013). Unfortunately, Denmark and the U.S. are not part of the survey.
} 
Figure 5: Odds Ratios for Coping Mechanisms, Country Intercepts

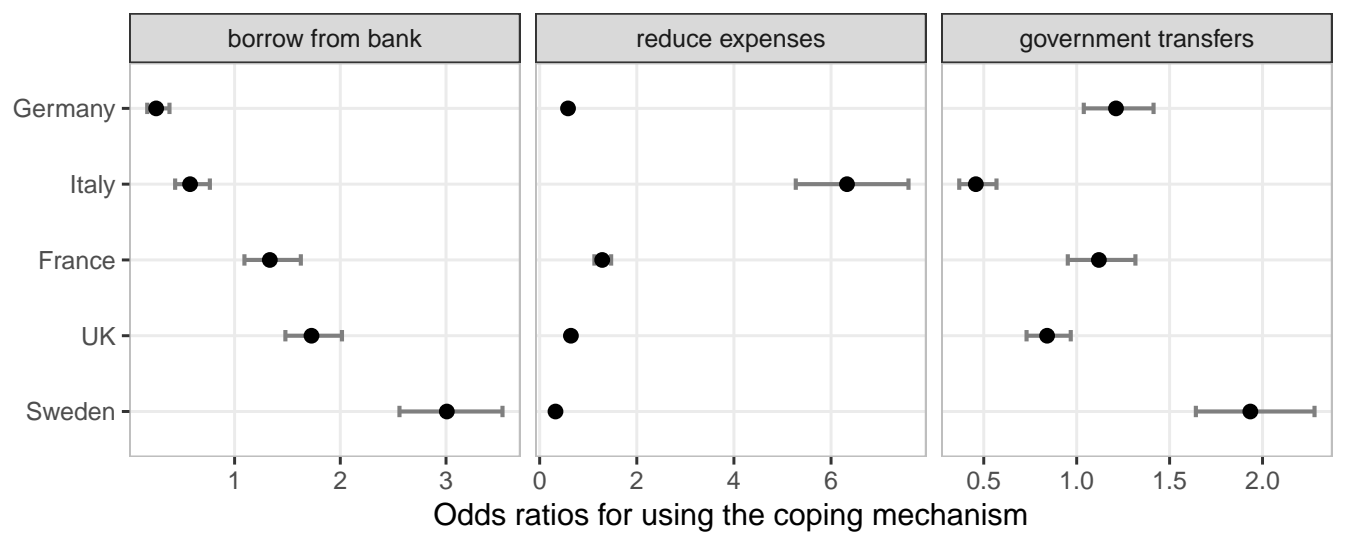

Notes: Odds ratios from generalized linear mixed-effects models with country random effects and $95 \%$ confidence intervals. Questions: "In the past two years [2008, 2009], have you or anyone else in your household had to take any of the following measures as the result of a decline in income or other economic difficulty? In the past two years, have you or any member of your household tried to borrow money from anyone? (e.g. a friend, other person or institution)." Table A.3 in the online appendix shows the fixed effects regression coefficients.

easy access to credit do households go into debt to address social policy-related financial shortfalls. I empirically substantiate this claim by comparing how the relationship between household indebtedness and welfare state generosity varies as a function of a country's credit regime permissiveness.

Since the credit regime permissiveness scores capture comparative statics, I use the IMF's Financial Development Index as an approximation of credit regime permissiveness. This index is advantageous because it covers more countries and, more importantly, a longer time horizon. ${ }^{9}$ While this index is no perfect measure of credit regimes, it positively correlates with credit regime permissiveness scores as shown in Figure 4a. I measure the generosity of social insurance system using unemployment insurance (UI) replacement rates for a single person at $100 \%$ earnings from the Comparative Welfare Entitlements Dataset. ${ }^{10}$ Data on household debt come from the BIS Total Credit Statistics, measured as total credit to the household sector. I estimate the relationship between social policy generosity and household debt as a function of the permissiveness of credit regimes in the following fixed-effect regression framework:

$$
Y_{i t}=\beta_{1} R+\beta_{2} F+\beta_{3}(R \cdot F)+\gamma \mathbf{X}_{i t}^{\prime}+\alpha_{i}+\delta_{t}+\epsilon_{i t}
$$

where $Y_{i t}$ is the debt-to-GDP ratio in country $i$ in year $t . R$ is the unemployment insurance

\footnotetext{
${ }^{9}$ Figure A.3 in the online appendix shows the index's cross-national and over-time variation.

${ }^{10}$ Scruggs, Lyle, Detlef Jahn, and Kati Kuitto. 2017. "Comparative Welfare Entitlements Dataset 2."
} 
replacement rate, ranging from 0 to $100 . F$ is the IMF's financial development index, ranging from 0 (least developed) to 1 (most developed). $\beta_{3}$ captures the interaction effect of UI replacement rates at different levels of financial development. $\alpha_{i}$ and $\delta_{t}$ are state and year fixed effects, controlling for time-invariant unobserved heterogeneity across countries and common aggregate time shocks, respectively.

The results, displayed in Figure 6, show that the permissiveness of a country's credit regime, approximated by the overall level of financial development, has a strong negative influence on the relationship between the generosity of social insurance and household debt levels. Substantively, a decline in the UI replacement rate by ten percentage points is associ-

Figure 6: Predicted Levels of Household Debt by Unemployment Insurance Generosity and Financial Development

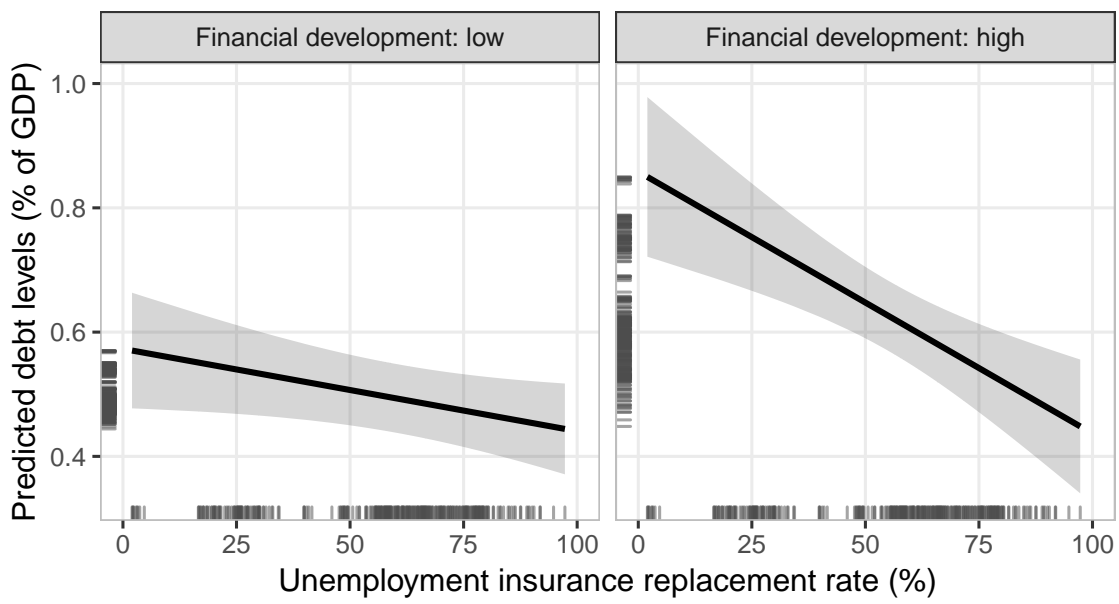

Notes: Predicted levels of total credit to households (\% of GDP) by UI replacement rates for countries with low and high levels of financial development. The results are based on model (2) in Table A.4 in the Appendix. 95\% confidence intervals based on bootstrapped standard errors clustered at the country level.

ated with an increase in debt-to-GDP levels by around five percentage points. By contrast, when financial development is low and access to credit more restricted, the generosity of unemployment insurance has a much smaller effect on household debt levels. Even though the results hinge on an imperfect approximation of credit access and, despite country and year fixed effects, should be viewed as correlational rather than causal, the findings provide strong support for the argument that credit only emerges as a substitute for social policies when credit regimes are permissive. 


\section{Borrowing During Unemployment: Evidence from Denmark and the U.S.}

The evidence so far demonstrates a macro-level substitution effect between credit regimes and welfare states. But we do not know which households are borrowing and how this is related to their social policy coverage. I address these questions in this final part by comparing to what extent individuals in the U.S. and Denmark go into debt and borrow money when they become unemployed. Both countries share permissive credit regimes and flexible labor market but crucially differ in the scope and breadth of their respective welfare regimes. Denmark provides generous unemployment benefits with replacement rate for singles and single-earner couples of $85 \%$ for low-income groups, but due to relatively low caps on maximum payouts, the effective rate drops sharply to around $50 \%$ for upper-middle and high-income groups. In the U.S., low-income singles and one-earner couples receive only around $60 \%$ of their prior wage, whereas those in the high-income group only receive $30 \%$. These differences in replacement rates become even larger for long-term unemployment. Five years out of the job, Danish low-income single households still receive $75 \%$, whereas low-income American singles only get 9\% (OECD Tax-Benefit Model, 2018). Note that in the U.S. replacement rates should be seen as the upper bound of financial support because less than $40 \%$ of all unemployed individuals actually receive unemployment benefits due to eligibility criteria and differential recipiency rates (McHugh and Kimball 2015).

Given these strong differences in coverage and financial support by the respective welfare states, I expect that low-income households in Denmark with high replacement rates borrow little, whereas higher-income households facing larger financial shortfalls borrow more. In the U.S., shortfalls tend to affect households across the income spectrum but borrowing should be higher among lower-income groups, not least because they have few other financial means to address income shocks. ${ }^{11}$ I test these predictions using full-population administrative register data in Denmark and panel data from the Survey of Income and Program Participation (SIPP) in the U.S.

Figure 7 plots unsecured debt-to-income ratios across income tertiles in Denmark and the U.S., indicating that these predictions are borne out in the data. Debt leverage has on average increased in both countries, but there are strong differences across income groups. In

\footnotetext{
${ }^{11}$ In 2015 only $46 \%$ of adults could not cover emergency expenses of $\$ 400$ without selling assets or borrow money (Federal Reserve. 2016. Report on the Economic Well-Being of U.S. Households in 2015. Washington D.C. Board of Governors of the Federal Reserve System).
} 
Denmark, debt leverage is much higher among high-income groups, whereas in the U.S. debt leverage is much stronger among low-income groups, indicating substantial differences in patterns of indebtedness across income groups. In the following sections, I formally estimate the effect of unemployment and income loss on unsecured debt in both countries.

Figure 7: Unsecured Debt-to-Income Ratios by Income Group

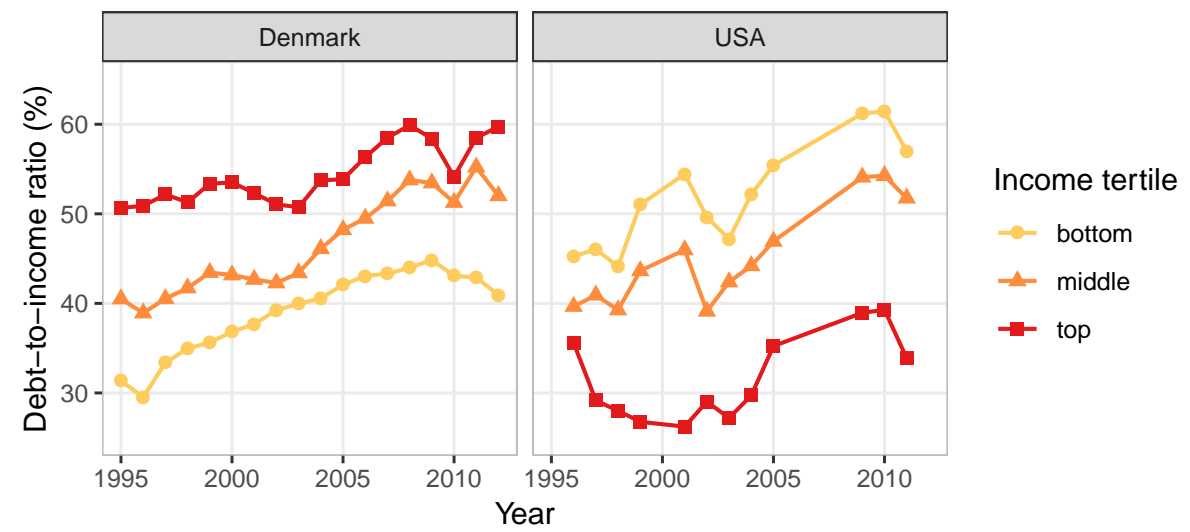

Note: The figure shows unsecured debt as a share of disposable income among unemployed individuals. Sources: Full-population Danish administrative data; SIPP.

\subsection{Divided Protection: Credit as Complement in Denmark}

In Denmark, I study the effect of involuntary unemployment on indebtedness in an event study framework. This design is based on changes in the outcome of interest, $Y_{i t}$, in response to unemployment occurring in year $\bar{t}_{i}$ for individual $i$. It estimates the outcome relative to the year prior to the event, essentially making comparisons about changes in outcomes relative to the time before the event when the outcome was not affected by the event. The model captures the effect of each year before and after the event happens in year $\bar{t}_{i}=0$ by defining an event-dummy vector for each individual $i$ ranging from $L$ years before and $F$ years after the event happens such that

$$
\mathcal{L}=T=\{-L, \ldots,-2,0,1, \ldots, F\}
$$

I chose the event window to range from five years before to five years after the event occurs, resulting in a matrix of eleven event-years per individual. The year prior to the event $(L=T=-1)$ serves as the omitted baseline category such that all estimated coefficients are relative to that year.

This design is well suited for high-quality administrative records with a long time-frame since the estimation requires sufficient individual-year observations before and after the event 
to draw inferences. In the Danish full population data, I observe all individuals before and after such an event occurs and can estimate whether unemployment leads to an increase in debt as well as if the size of the income loss correspondents to a commensurate debt increase. To estimate the effect cleanly, I only consider household heads who experience an unemployment spell of at least two consecutive years and who were employed for at least two consecutive years before the unemployment spell. Since individuals may experience more than one spell of unemployment during their time in the panel, I select the first year the head becomes unemployment as the beginning of the spell and then construct a balanced panel of individuals who are observed for at least five years before and five years after unemployment began $(T=-5$ to $T=+5)$. I then estimate the following OLS regression model:

$$
Y_{i t}=\sum_{\ell \in \mathcal{L}}\left(\beta_{\ell} \cdot \mathbb{1}\left\{t=\bar{t}_{i}+\ell\right\}\right)+\mathbf{X}_{i t}^{\prime} \gamma+\alpha_{t}+\delta_{c[i]}+\sigma_{z[i]}+\epsilon_{i t}
$$

where $Y_{i t}$ is the $\log$ unsecured debt level of individuals $i$ in year $t .{ }^{12} \mathbf{X}_{i t}^{\prime}$ is a vector of timeand individual-varying controls including age square, education dummies, savings-to-income ratio, income quintiles, a measure of how many days the individual was unemployed in a given year, male, single, number of children, and unemployment insurance membership. $\alpha_{t}, \delta_{c}$, and $\sigma_{z}$, are year, birth-year, and ZIP code fixed effects, respectively. Year fixed effects control for common aggregate time effects such as the business cycle, national interest rates, asset prices, or wage inflation that can otherwise drive borrowing behavior. Birth-year fixed effect control for life-cycle and cohort effects as well as trends in individuals' career progression and address concerns that, for example, younger adults may have more debt than older ones. In other model specifications I also include ZIP code-year trends to allow for heterogeneous effects across ZIP code areas over time. $\epsilon_{i t}$ is the idiosyncratic error term.

Figure $8 \mathrm{a}$ shows the event-year coefficients of debt levels in response to unemployment based on the baseline event study model in equation 3. In the years prior to unemployment, debt levels follows a flat path. Yet once the household head becomes unemployed $(t=$ 0 ), debt levels increase sharply by almost $150 \%$ relative to the level in the year before the unemployment spell began. Note that the year prior to the event $(t=-1)$ is the model's baseline and therefore omitted. Two years after the unemployment spell began,

\footnotetext{
${ }^{12}$ Households' assets and liabilities are highly skewed, but a natural log transformation is problematic since it is undefined at zero. Since many households have zero assets and liabilities, it is important to keep them in the sample. To address this problem, I resort to a commonly-used inverse hyperbolic sine transformation defined for variable $z$ as $\sinh ^{-1} z=\ln \left(z+\sqrt{1+z^{2}}\right)$ in which negative values and zero in $z$ are defined. This transformation is linear around the origin, approximates a log transformation at the right tail, and can be interpreted as a standard logarithmic variable (see Pence 2006).
} 
Figure 8: Marginal Effects of Unemployment Spells on Unsecured Debt in Denmark

(a) Baseline Effect

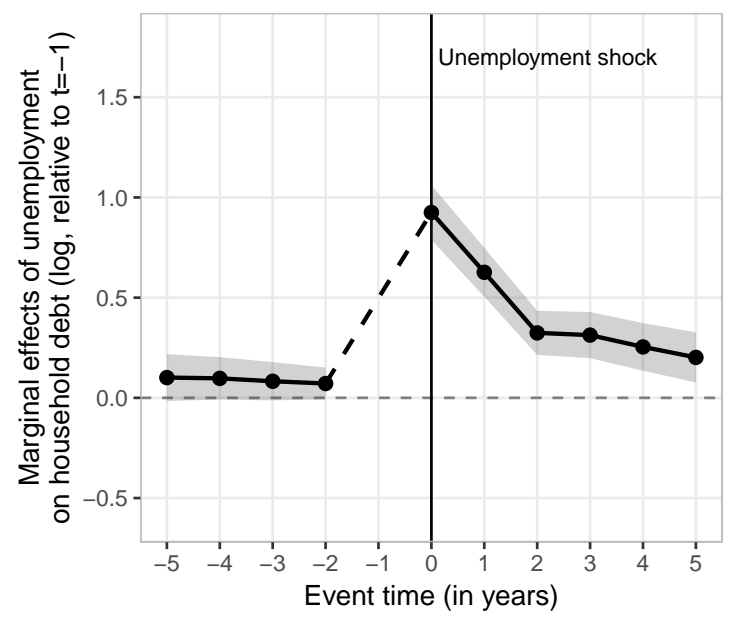

(b) By Size of Financial Shortfall

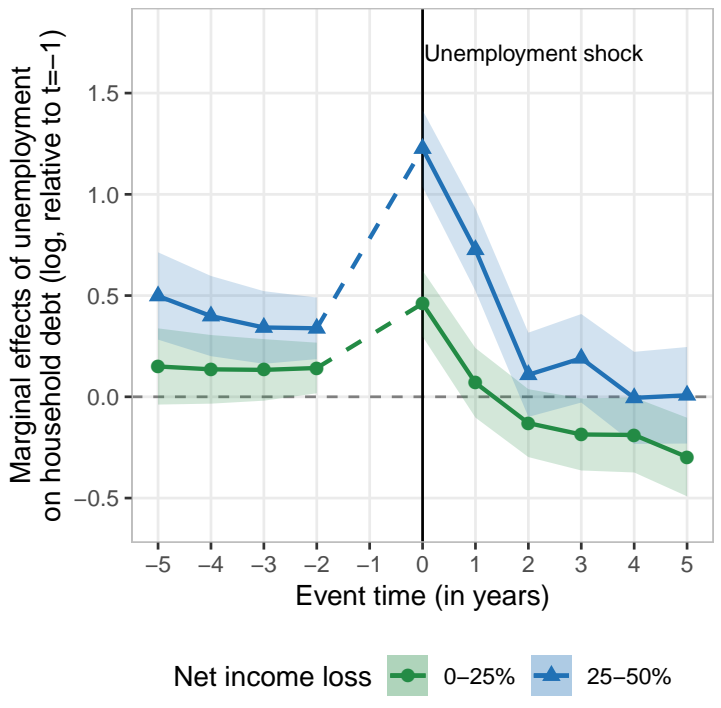

Notes: The plots shows event-year marginal effect coefficients relative to the year prior to unemployment $(t=0)$ based on equation 3. The year prior to the event $(t=-1)$ is the omitted baseline. The shaded areas are 95\% confidence intervals based on robust standard errors clustered at the household level. The model is based on a balanced sample of households whose household head experiences his or her first unemployment spell between 1992-2007 such that households are observed during the entire period between five years before and after unemployment.

debt levels have declined, even if not completely to pre-unemployment levels, supporting the argument that households are borrowing money to address temporary income losses caused by unemployment.

How does this effect vary depending on the size of the financial shortfalls? Since the amount of unemployment benefits varies across the income spectrum, with low-income groups receiving a higher replacement rate than higher-income groups, we would expect to see different debt levels after job loss depending on the size of the social policy-related financial shortfall. To shed light on this relationship, I calculate how much households' disposable income declines as a consequence of unemployment. This approach takes into account government transfers and is a direct measure of households' varying financial burden during unemployment. I divide households according to the size of their net income loss when the household head became unemployed, resulting in the following two groups: those with a net income loss of up to $25 \%$ of prior income and those with a net income loss between $25 \%$ and 
$50 \%$. I then separately estimate the event study based on equation 3 for both income loss groups.

Figure 8b shows the event-year coefficients for each income-loss group over the event window. Prior to unemployment, the debt trajectories within each income loss group follows a similar flat trend, satisfying the parallel trend assumption to ensure unbiased results. Once struck by unemployment, households that experience larger social policy shortfalls also borrow more. A net income loss of up to $25 \%$ increases debt levels by 1.7 times relative to levels in the year prior. Yet those losing between 25\% and 50\% of prior net income, typically higher-income groups, borrow even more, almost three times relative to the baseline. As before, debt levels have returned to the pre-unemployment levels after around two years, indicating that households use credit to smooth temporary income losses. In sum, the event study results suggest that there is a strong increase in unsecured debt following unemployment spells, especially among households that have larger financial shortfalls.

\subsection{Limited Protection: Credit as Substitute in the U.S.}

How does the Danish case with its permissive credit regime, flexible labor markets, and comprehensive but divided social insurance, compare to the U.S. case, where labor markets and credit regimes are equally flexible and permissive, respectively, but social policies far less comprehensive? Administrative data or long-run panel data that include annual debt levels and would allow me to estimate a similar event study are unfortunately not available. ${ }^{13}$ I therefore use data from the Survey of Income and Program Participation (SIPP), a household-based survey designed as a continuous series of national panels of multi-year periods. ${ }^{14}$ I combine the annual topic modules on assets and liabilities with the main survey for the 1996, 2001, 2004, and 2008 period-panels. The SIPP records households' unsecured debt, which includes credit card debt, unsecured loans from financial institutions, outstanding bills including medical bills, loans from individuals, and educational loans.

To compare the Danish case to the extent to which American households take on debt to address income losses caused by disruptions in employment patterns, I estimate how debt levels change when individuals switch from full-time employment into unemployment or absence from work in the following generalized difference-in-differences regression framework:

$$
Y_{i t}=\beta \mathbf{E}_{i t}+\mathbf{X}_{i t}^{\prime} \gamma+\alpha_{i}+\delta_{t}+\epsilon_{i t}
$$

\footnotetext{
${ }^{13}$ The PSID switched to a biannual survey and is therefore not suitable for event studies.

${ }^{14}$ For a detailed description of the data and the construction of variables see Section A.1 in the Appendix.
} 
where $Y_{i t}$ is the unsecured debt (in $\log$ ) for individual $i$ in year $t . \mathbf{E}_{i t}$ is a dummy that takes the value of one if individual $i$ is either laid off or absent from work without layoff and zero if she is full-time employed. $\mathbf{X}_{i t}^{\prime}$ is a matrix of time-varying individual-level covariates such as education, age, number of children, marital status, homeowner, race, savings, and interest rates on mortgage payments. I also add controls for households' total income as well as for savings constraints, defined in line with the literature as households with less than 1.5 times their monthly income in savings (Johnson, Parker and Souleles 2006; Zeldes 1989). $\alpha_{i}$ and $\delta_{t}$ are individual and year fixed effects, respectively.

I estimate two separate models for layoff and for absence from work without layoff. I also allow the effect of changes in employment status to vary by income tertile by interacting the employment dummy with a vector of income tertiles. Figure 9 shows the results. With unit and year fixed effects, I estimate the effect of switching from full-time employment into either layoff or absence without layoff by essentially comparing changes within each respondent. When individuals are laid off from a full-time job or when they take a leave of absence

Figure 9: Marginal Effects of Employment Status on Unsecured Debt Levels by Income Groups in the U.S.

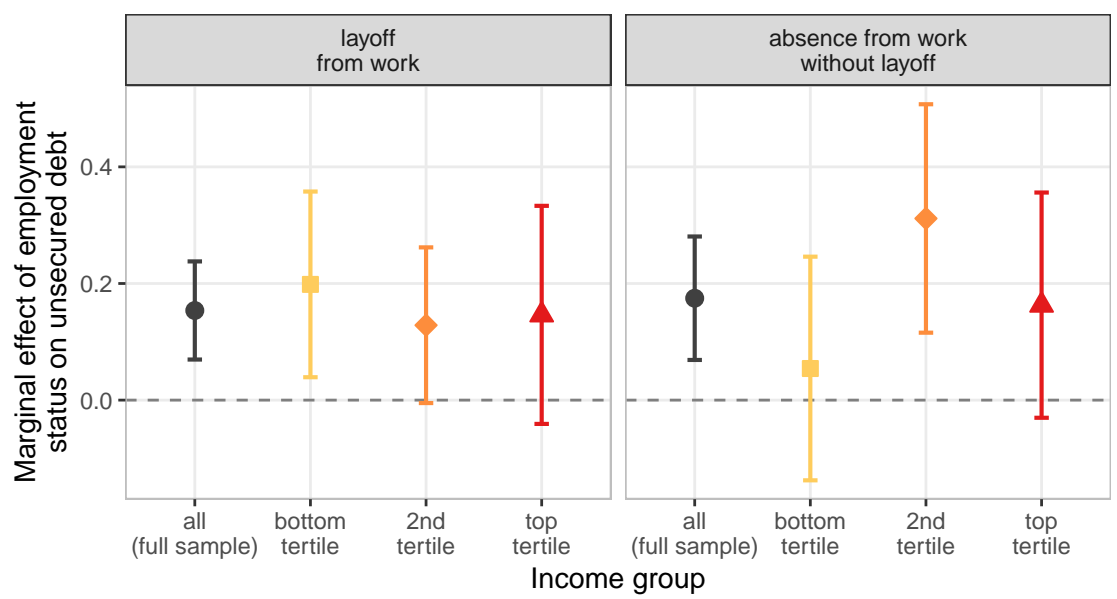

Notes: Marginal effects with 95\% confidence intervals. All coefficients are relative to full-time employed individuals, the omitted baseline. Full regression results in Table A.5 in the online appendix.

without being laid off, for example due to sickness or to care for children, their unsecured debt increases 1.2 times in both cases. I allow the estimate to vary across income groups by interacting the employment dummies with income tertiles. Outright job loss is associated with higher levels of unsecured debt across all income groups, but particularly strong among low- and middle-income groups. Borrowing in response to absence from work without being 
laid off, by contrast, is concentrated among middle- and, although statistically insignificant, higher-income groups. This reflects the combination of more voluntary forms of labor market exit and the associated opportunity costs with leaving work, typically temporarily, for reasons unrelated to job loss.

\section{Discussion and Conclusion}

In this paper, I offered a novel theoretical framework that identifies important links between credit markets and welfare states, arguing that households increasingly go into debt to pay for basic social services when credit regimes are permissive and financial shortfalls are large. The comparative perspective highlights two factors that shape households' coping strategies with social risks, reflecting variation in patterns of indebtedness across and within countries: first, the degrees to which individuals themselves rather than society and welfare states are responsible to address the shortfall that arises between, on the one hand, the financial consequences of fragmented and disrupted employment patterns and life course trajectories and, on the other hand, weak or incomplete social policies support due to welfare state retrenchment and policy drift. Second, the permissiveness of a country's credit regime and the degree to which households have access to credit and can borrow money to bridge these social policy-related shortfalls.

The findings of this paper paint a coherent picture that credit emerges as a private alternative to welfare states and highlights the mediating role of the structure of countries' credit regimes. In permissive credit regimes such as Sweden or the U.K., households are more likely to cope with income losses by borrowing money. In restrictive credit regimes such as Germany and Italy, by contrast, they are more likely to cut expenses and draw on savings. At the macro level, I further demonstrate that the negative relationship between welfare state generosity and household debt only emerges in cases where credit regimes are permissive. Finally, I show how the structure of the welfare regime interacts with the structure of the credit regime to constrain which households Denmark and the U.S.- two cases with permissive credit regimes, flexible labor markets, but different welfare regimesborrow money to address financial shortfalls. In Denmark, the permissive credit regime is layered on top of the welfare state and complements social policies for high-income groups who borrow money to address financial shortfalls. Low-income groups borrow little because they are comprehensively covered by the welfare state. In the U.S., by contrast, credit markets substitute for welfare states since coverage across the income spectrum is weak. For 
involuntary unemployment, low-income groups are most likely to borrow money, whereas for absence from work, often paid, for reasons unrelated to unemployment such as leave, sickness, or training, borrowing is more prevalent among middle- and high-income groups.

This paper raises further questions about the socio-economic and political consequences of growing household indebtedness and the links between credit markets and public policies. First, as financial markets and family wealth become important means to address the financial consequences of labor market risks and life course choices, differential credit access and wealth holdings can turn into socio-economic barriers. The cost of credit often varies by income, race, and geography, thus intensifying existing structural inequalities and wealth disparities (Dwyer 2018; Pager and Shepherd 2008; Thurston 2018). Moreover, the growing reliance on financial markets to finance education, acquire a home, or invest in other assets has compounding effects. Those with easy access to financial markets and sufficient wealth can effectively hoard opportunities by reaping the benefits of their private investment, often leveraging intergenerational wealth as parents take out educational loans on behalf of their children or front the down payment for housing. Others, however, may not be able to access credit or do so only with high opportunity costs. This constraints life chances, increase financial insecurity and, at worst, leads to arrears and bankruptcy when debt repayments become unsustainable.

Second, the rising influence of financial markets may have downstream political consequences that merit further investigation. Financial markets create vested interests that favor pro-finance policies and want to protect the benefits of their private investment. This often comes at the expense of public and tax-funded policies for those who cannot draw on financial markets. Accountability shifts further away from the political arena into the realm of business, exposing tensions between democracy and markets. It is worth reiterating that credit markets are not substitutes for welfare states. Social policies are based on eligibility rules that are politically determined, whereas access to and the cost of credit depend on business considerations of private lenders. Credit, after all, is not a social right. For policymakers, by contrast, financial markets are convenient because they avoid contentious decisions and rarely add to the budget, further consolidating "hidden" and "submerged" policymaking that transforms the social policy landscape (e.g. Howard 1997; Mettler 2011). If policymakers are more responsive to voters that favor pro-credit policies at the expense of tax-funded public policies, the government might retreat even more and exclude individuals who depend most on it, which in turn could further undermining support for the welfare state and social solidarity. 


\section{References}

Ahlquist, John S. and Ben W. Ansell. 2017. "Taking Credit: Redistribution and Borrowing in an Age of Economic Polarization." World Politics 69(4):640-675.

Allan, James P. and Lyle Scruggs. 2004. "Political Partisanship and Welfare State Reform in Advanced Industrial Societies." American Journal of Political Science 48(3):496-512.

Allen, Franklin and Douglas Gale. 2000. Comparing Financial Systems. Cambridge, Mass: MIT Press.

Ameriks, John, Andrew Caplin and John Leahy. 2003. "Wealth Accumulation and the Propensity to Plan." The Quarterly Journal of Economics 118(3):1007-1047.

Andrews, Dan, Aida Caldera Sánchez and Åsa Johansson. 2011. Housing Markets and Structural Policies in OECD Countries. OECD Economics Department Working Papers Paris: Organisation for Economic Co-operation and Development.

Ansell, Ben. 2014. "The Political Economy of Ownership: Housing Markets and the Welfare State." American Political Science Review 108(02):383-402.

Baccaro, Lucio and Jonas Pontusson. 2016. "Rethinking Comparative Political Economy: The Growth Model Perspective." Politics 8 Society 44(2):175-207.

Baldwin, Peter. 1990. The Politics of Social Solidarity: Class Bases of the European Welfare State, 1875-1975. Cambridge; New York: Cambridge University Press.

Barr, Nicholas. 2001. The Welfare State as Piggy Bank: Information, Risk, Uncertainty, and the Role of the State. Oxford: Oxford University Press.

Barth, James R., Ross Levine and Gerard Caprio. 2013. "Bank Regulation and Supervision in 180 Countries from 1999 to 2011." Journal of Financial Economic Policy 5(2):111-219.

Becker, Gary S. 1976. The Economic Approach to Human Behavior. Chicago: University of Chicago Press.

Benartzi, Shlomo and Richard H. Thaler. 1995. "Myopic Loss Aversion and the Equity Premium Puzzle." The Quarterly Journal of Economics 110(1):73-92.

Browning, Martin and Thomas F. Crossley. 2001. "The Life-Cycle Model of Consumption and Saving." The Journal of Economic Perspectives 15(3):3-22.

Castles, Frank. 1998. "The Really Big Trade-off: Home Ownership and the Welfare State in the New World and the Old." Acta Politica 33(1):5-19.

Cerutti, Eugenio, Jihad Dagher and Giovanni Dell'Ariccia. 2017. "Housing Finance and RealEstate Booms: A Cross-Country Perspective." Journal of Housing Economics 38:1-13. 
Clark, Gordon L. 2000. Pension Fund Capitalism. Oxford; New York: Oxford University Press.

Conley, Dalton and Brian Gifford. 2006. "Home Ownership, Social Insurance, and the Welfare State." Sociological Forum 21(1):55-82.

Crouch, Colin. 2009. "Privatised Keynesianism: An Unacknowledged Policy Regime." The British Journal of Politics \& International Relations 11(3):382-399.

Culpepper, Pepper D. 2005. "Institutional Change in Contemporary Capitalism: Coordinated Financial Systems since 1990." World Politics 57(2):173-199.

DIW. 2009. "Real Wages in Germany: Numerous Years of Decline." DIW Weekly Report $5(28): 193-202$.

Dwyer, Rachel E. 2018. "Credit, Debt, and Inequality." Annual Review of Sociology 44(1):237-261.

Emmenegger, Patrick, Silja Häusermann, Bruno Palier and Martin Seeleib-Kaiser. 2012. The Age of Dualization: The Changing Face of Inequality in Deindustrializing Societies. Oxford: Oxford University Press.

Engelen, Ewald and Martijn Konings. 2010. Financial Capitalism Resurgent: Comparative Institutionalism and the Challenges of Financialization. In The Oxford Handbook of Comparative Institutional Analysis, ed. Glenn Morgan, John L. Campbell, Colin Crouch, Ove Kaj Pedersen and Richard Whitley. Oxford: Oxford University Press pp. 601-624.

Esping-Andersen, Gøsta. 1990. The Three Worlds of Welfare Capitalism. Princeton: Princeton University Press.

Esping-Andersen, Gøsta. 1999. Social Foundations of Postindustrial Economies. Oxford: Oxford University Press.

Fligstein, Neil and Adam Goldstein. 2015. "The Emergence of a Finance Culture in American Households, 1989-2007." Socio-Economic Review 13(3):575-601.

Frank, Robert H. 2010. Luxury Fever: Weighing the Cost of Excess. Princeton: Princeton University Press.

Fuller, Gregory W. 2015. "Who's Borrowing? Credit Encouragement vs. Credit Mitigation in National Financial Systems." Politics \& Society 43(2):241-268.

Gathergood, John. 2012. "Self-Control, Financial Literacy and Consumer OverIndebtedness." Journal of Economic Psychology 33(3):590-602.

Goyer, Michel. 2006. "Varieties of Institutional Investors and National Models of Capitalism: The Transformation of Corporate Governance in France and Germany." Politics 65 Society 34(3):399-430. 
Hacker, Jacob S. 2004. "Privatizing Risk without Privatizing the Welfare State: The Hidden Politics of Social Policy Retrenchment in the United States." American Political Science Review 98(02):243-260.

Hacker, Jacob S. 2008. The Great Risk Shift: The Assault on American Jobs, Families, Health Care and Retirement and How You Can Fight Back. Oxford: Oxford University Press.

Hall, Peter A. and David W. Soskice. 2001. Varieties of Capitalism: The Institutional Foundations of Comparative Advantage. Oxford: Oxford University Press.

Hassel, Anke, Marek Naczyk and Tobias Wiß. 2019. "The Political Economy of Pension Financialisation: Public Policy Responses to the Crisis." Journal of European Public Policy $0(0): 1-18$.

Häusermann, Silja. 2010. The Politics of Welfare State Reform in Continental Europe: Modernization in Hard Times. New York: Cambridge University Press.

Hemerijck, A. 2013. Changing Welfare States. Oxford: Oxford University Press.

Howard, Christopher. 1997. The Hidden Welfare State: Tax Expenditures and Social Policy in the United States. Princeton, N.J.: Princeton University Press.

Huber, Evelyne and John D Stephens. 2001. Development and Crisis of the Welfare State: Parties and Policies in Global Markets. Chicago: University of Chicago Press.

Jappelli, Tullio and Marco Pagano. 1994. "Saving, Growth, and Liquidity Constraints." The Quarterly Journal of Economics 109(1):83-109.

Johnson, David S., Jonathan A. Parker and Nicholas S. Souleles. 2006. "Household Expenditure and the Income Tax Rebates of 2001." The American Economic Review 96(5):15891610.

Kaplan, Greg, Giovanni L. Violante and Justin Weidner. 2014. "The Wealthy Hand-toMouth." Brookings Papers on Economic Activity 2014(1):77-138.

Kiviat, Barbara. 2017. "The Art of Deciding with Data: Evidence from How Employers Translate Credit Reports into Hiring Decisions." Socio-Economic Review pp. 1-27.

Krippner, Greta R. 2011. Capitalizing on Crisis: The Political Origins of the Rise of Finance. Harvard University Press.

Kumhof, Michael, Romain Rancière and Pablo Winant. 2015. "Inequality, Leverage, and Crises." American Economic Review 105(3):1217-1245.

La Porta, Rafael, Florencio Lopez-De-Silanes and Andrei Shleifer. 1999. "Corporate Ownership Around the World." The Journal of Finance 54(2):471-517.

Leon, Florian. 2018. The Credit Structure Database. Technical Report 18-07 Center for Research in Economic Analysis, University of Luxembourg. 
Lusardi, Annamaria. 2008. Overcoming the Saving Slump: How to Increase the Effectiveness of Financial Education and Saving Programs. Chicago: University of Chicago Press.

Mayer, Karl Ulrich. 2009. "New Directions in Life Course Research." Annual Review of Sociology 35(1):413-433.

McCarty, Nolan M., Keith T. Poole and Howard Rosenthal. 2013. Political Bubbles: Financial Crises and the Failure of American Democracy. Princeton: Princeton University Press.

McHugh, Rick and Will Kimball. 2015. How Low Can We Go? State Unemployment Insurance Programs Exclude Record Numbers of Jobless Workers. Briefing Paper \#392 Washington, D.C.: Economic Policy Institute.

Mertens, Daniel. 2017. "Borrowing for Social Security? Credit, Asset-Based Welfare and the Decline of the German Savings Regime." Journal of European Social Policy .

Mettler, Suzanne. 2011. The Submerged State. How Invisible Government Policies Undermine American Democracy. Chicago: University Of Chicago Press.

Mian, Atif and Amir Sufi. 2014. House of Debt: How They (and You) Caused the Great Recession, and How We Can Prevent It from Happening Again. Chicago: University Of Chicago Press.

Montgomerie, Johnna. 2013. "America's Debt Safety-Net." Public Administration 91(4):871888.

Morduch, Jonathan and Rachel Schneider. 2017. The Financial Diaries: How American Families Cope in a World of Uncertainty. Princeton, N.J.: Princeton University Press.

OECD. 2018. Pension Markets in Focus. Paris: OECD Publishing.

Pager, Devah and Hana Shepherd. 2008. "The Sociology of Discrimination: Racial Discrimination in Employment, Housing, Credit, and Consumer Markets." Annual Review of Sociology 34(1):181-209.

Pence, Karen M. 2006. "The Role of Wealth Transformations: An Application to Estimating the Effect of Tax Incentives on Saving." The B.E. Journal of Economic Analysis \& Policy $5(1)$.

Pierson, Paul. 2001. The New Politics of the Welfare State. Oxford: Oxford University Press.

Porter, Katherine, ed. 2012. Broke: How Debt Bankrupts the Middle Class. Stanford, California: Stanford University Press.

Prasad, Monica. 2012. The Land of Too Much: American Abundance and the Paradox of Poverty. Cambridge, MA: Harvard University Press. 
Rajan, Raghuram G. 2010. Fault Lines: How Hidden Fractures Still Threaten the World Economy. Princeton, N.J: Princeton University Press.

Rehm, Philipp, Jacob S. Hacker and Mark Schlesinger. 2012. "Insecure Alliances: Risk, Inequality, and Support for the Welfare State." American Political Science Review 106(02):386-406.

Sanfey, Peter. 2013. People and Transition: Life in Transition Survey. In Handbook of the Economics and Political Economy of Transition, ed. Paul Hare and Gerard Turley. New York: Routledge pp. 313-320.

Schmid, Günther. 2002. Towards a Theory of Transitional Labour Markets. In The Dynamics of Full Employment: Social Integration Through Transitional Labour Markets, ed. Günther Schmid and Bernard Gazier. Cheltenham, U.K.: Edward Elgar pp. 151-195.

Schularick, Moritz and Alan M. Taylor. 2012. "Credit Booms Gone Bust: Monetary Policy, Leverage Cycles, and Financial Crises, 1870-2008." American Economic Review 102(2):1029-61.

Schwartz, Herman. 2008. "Housing, Global Finance, and American Hegemony: Building Conservative Politics One Brick at a Time." Comparative European Politics 6(3):262-284.

Schwartz, Herman M and Leonard Seabrooke. 2009. The Politics of Housing Booms and Busts. Basingstoke; New York: Palgrave Macmillan.

Stiglitz, Joseph E. 2015. "8. Inequality and Economic Growth." The Political Quarterly 86(S1):134-155.

Streeck, Wolfgang and Kozo Yamamura. 2001. The Origins of Nonliberal Capitalism: Germany and Japan in Comparison. Ithaca: Cornell University Press.

Svirydzenka, Katsiaryna. 2016. "Introducing a New Broad-Based Index of Financial Development." IMF Working Paper WP/16/5.

Thelen, Kathleen. 2004. How Institutions Evolve: The Political Economy of Skills in Germany, Britain, the United States, and Japan. Cambridge: Cambridge University Press.

Thurston, Chloe N. 2018. At the Boundaries of Homeownership: Credit, Discrimination, and the American State. Cambridge: Cambridge University Press.

Turunen, Elina and Heikki Hiilamo. 2014. "Health Effects of Indebtedness: A Systematic Review." BMC Public Health 14(1):489.

Warren, Elizabeth and Amelia Warren Tyagi. 2003. The Two-Income Trap: Why MiddleClass Mothers and Fathers Are Going Broke. New York: Basic Books.

Weil, David. 2014. The Fissured Workplace: Why Work Became so Bad for so Many and What Can Be Done to Improve It. Cambridge: Harvard University Press.

World Bank. 2017. Global Financial Development Database. Washington, D.C.: World Bank. 
Zeldes, Stephen P. 1989. "Consumption and Liquidity Constraints: An Empirical Investigation." Journal of Political Economy 97(2):305-346.

Zysman, John. 1983. Governments, Markets, and Growth: Financial Systems and the Politics of Industrial Change. Ithaca, N.Y.: Cornell University Press. 


\section{Online Supplemental Appendix}

\section{A.1 Data Sources and Variable Construction for Panel Data}

The datasets used in this project are harmonized according to the following principles. All individual-level data is aggregated to the household level to take into account resource sharing within the household. I use to terms "household" and "family" interchangeably to capture the same underlying unit. The household head is, in line with most household-level datasets, the male person of that household. I subset all datasets to working-age individuals between the ages of 15 and 65 and exclude self-employed individuals as this group might have loans for business purposes that cannot be identified separately in the datasets. All data is inflationadjusted.

\section{Danish Administrative Register Data}

In the Danish case, I use several high-quality administrative records gathered by Statistics Denmark that cover, for most variables, the entire Danish population since 1987. I link these registers based on unique anonymized personal identification numbers (CPR number) that are assigned at birth. This allows me to combine different registers at the individual level into a large panel dataset that spans several decades and contains around 55 million observations or around ca. 4.4 million unique household heads. The registers contain detailed information on individuals' demographic characteristics, household composition, labor market attachment and social policy program participation, income and government transfers, and wealth. Data on income and wealth is based on administrative tax returns collected by the Danish Tax Agency (SKAT) and supplemented by information from third-party reporting such as banks and other financial institutions reported to the tax authorities at the end of the year. I obtained fine-grained information on individuals' liabilities including bank and mortgage loans as well as complete portfolio information including the value of stock and bond ownership and cash in bank accounts. Labor market information comes from the register-based Labor Force Statistics (RAS Statistics) and the Integrated Database for Labor Market Research (IDA). For more information on the Danish registers see, for example, Petersson, Baadsgaard and Thygesen (2011).

The data is unique in its quality because it covers the entire Danish population over a very long time horizon. The data is not self-reported by individuals and therefore contains minimal measurement error and does not top-code assets, liabilities, and incomes. Unlike in survey-based panels, there is virtually no missing data or attrition.

In the Danish register data, a household is defined as all individuals living at the same address if they are either a registered or married couple, have at least one joint child according to the civil register, or are of the opposite sex with an age difference of less than 15 years, unrelated, and live with no other adults. All other adults living at the same address are counted as members of different families. Children are part of a family if they are registered at the same address as at least one parent, are under 25 years old, have never been married or in a civil partnership, do not have children of their own, and are not part of a cohabiting couple. I use household and family interchangeably. To ensure comparability with other 
countries, the default household head is the man in the case of a couple (married or not); when the household consists of a woman alone, she is the head.

\section{Survey of Income and Program Participation (U.S.)}

The Survey of Income and Program Participation (SIPP) is a household-based survey administered by the Census Bureau and designed as a continuous series of national panels. It uses a two-stage stratified design to produce a nationally representative panel of respondents who are interviewed over a period of approximately three to four years. Within a SIPP panel, the entire sample is interviewed at various waves, generally four-month intervals. In addition to income, assets, and liabilities and public program participation, the SIPP includes data on other factors of economic well-being, demographics, and household characteristics.

I use the SIPP instead of the Panel Survey of Income Dynamics (PSID) because it contains data on household liabilities for every year of the wave. Other panel datasets such as the PSID switched to a biannual data collection and are therefore not helpful to study borrowing choices in response to income losses.

\section{Variable Constructions}

Unsecured debt in each country consists of the following categories. In Denmark it is based on administrative data and includes bank loans, credit card debt (included since 1990), and student loans (included since 1991). Bank loans may include a fraction of mortgage debt because of financing requirements of Danish mortgage lenders. Individuals who take out a mortgage have to finance part of the mortgage, often the down payment, through a bank loan. This fraction is typically less than 20 percent of the total purchase value. To address this issue, unsecured debt is based on the non-home owning population. In the U.S. it includes installment loans, credit card balances, other debts, other lines of credit. In Germany unsecured debt includes loans from banks, loans from family and friends, and other bank loans. 


\section{A.2 Background on Credit Regime Permissiveness Scores}

Table A.1: Overview of Credit Regime Indicators and their Data Sources

\begin{tabular}{lll}
\hline \hline Dimension & Measure & Data Source \\
\hline (1) Financial market depth & $\begin{array}{l}\text { ○ Stock market capitalization (\% GDP) } \\
\text { ○ Total pension assets (\% GDP) }\end{array}$ & $\begin{array}{l}\text { World Bank (2017) } \\
\text { OECD (2018) }\end{array}$ \\
\hline $\begin{array}{l}\text { (2) Allocation of credit between } \\
\text { businesses and households }\end{array}$ & $\begin{array}{c}\text { o Lending to business sector } \\
\text { (as \% of total lending) }\end{array}$ & Leon (2018) \\
\hline $\begin{array}{l}\text { (3) Regulatory and fiscal incentives } \\
\text { for credit formation in the } \\
\text { housing market }\end{array}$ & $\begin{array}{l}\text { ○ Maximum LTV ratios } \\
\text { ○ Tax relief for debt-financed } \\
\text { homeownership }\end{array}$ & Barth et al. (2013) \\
\hline \hline
\end{tabular}

Table A.2: Factor Loadings for Credit Regime Indicators

\begin{tabular}{lrrrrr}
\hline \hline Variable & RC1 & RC2 & h2 & u2 & com \\
\hline Stock market capitalization (\% GDP) & $\mathbf{0 . 8 7}$ & 0.18 & 0.79 & 0.21 & 1.08 \\
Total pension assets (\% GDP) & $\mathbf{0 . 8 6}$ & 0.22 & 0.79 & 0.21 & 1.13 \\
Lending to business sector (\% total bank lending) & $\mathbf{- 0 . 7 6}$ & $\mathbf{0 . 5 0}$ & 0.83 & 0.17 & 1.73 \\
Share government-owned banks (\% all banks) & -0.26 & $\mathbf{- 0 . 7 9}$ & 0.70 & 0.30 & 1.21 \\
Maximum LTV ratio & $\mathbf{0 . 5 6}$ & $\mathbf{0 . 3 2}$ & 0.42 & 0.58 & 1.58 \\
Tax relief for debt-financed homeownership & 0.06 & $\mathbf{0 . 7 3}$ & 0.54 & 0.46 & 1.01 \\
\hline SS loadings & 2.47 & 1.6 & & & \\
\hline \hline
\end{tabular}


Figure A.1: Raw Values of the Credit Regime Indicators
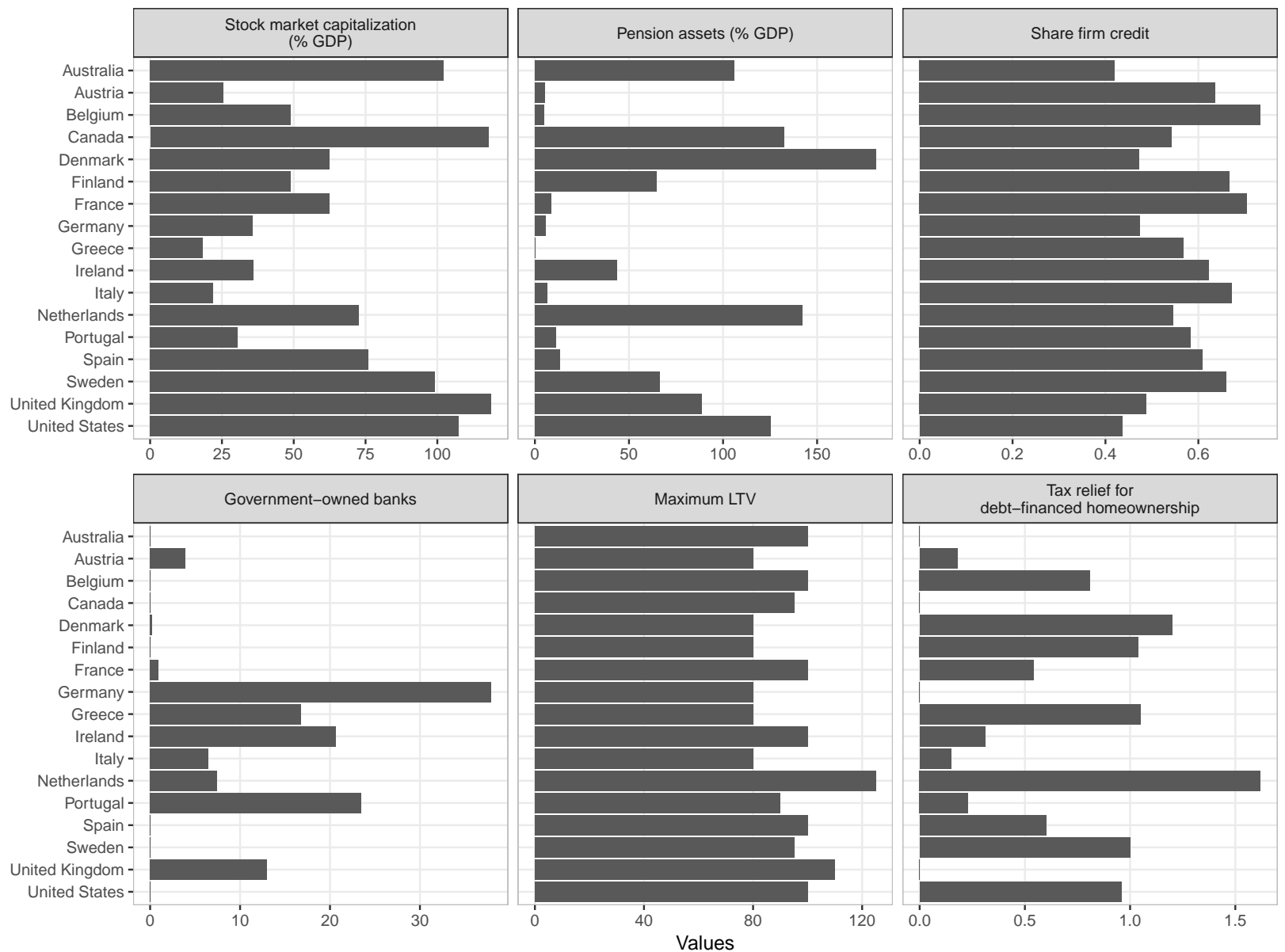

Notes: The indicators for government-owned banks and tax relief for debt-financed homeownership is zero for countries that do not have any government owned banks and do not offer tax relief, respectively. See Table A.1 for data sources. 
Figure A.2: Distribution of Countries Along the First Two Principal Components

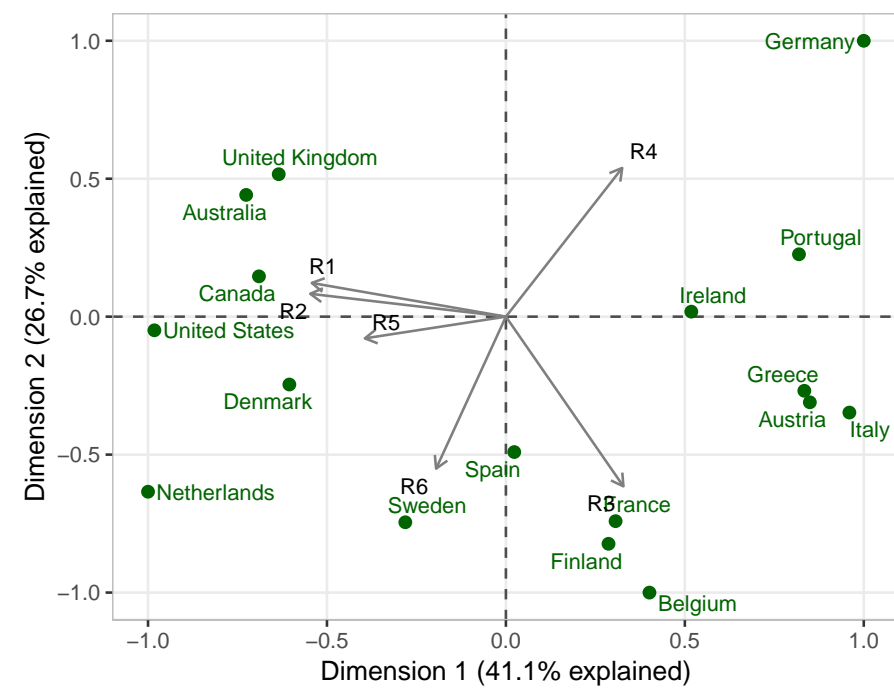

Indicators

R1: Stock market cap.

R2: Pension assets

R3: Lending to firms

R4: Gvt.-owned banks

R5: Maximum LTV

R6: Tax relief for debt-financed

homeownership

Notes: The plot shows the distribution of countries along the first two factors of the principal component analysis.

Figure A.3: IMF Financial Development Index for Advanced Economies

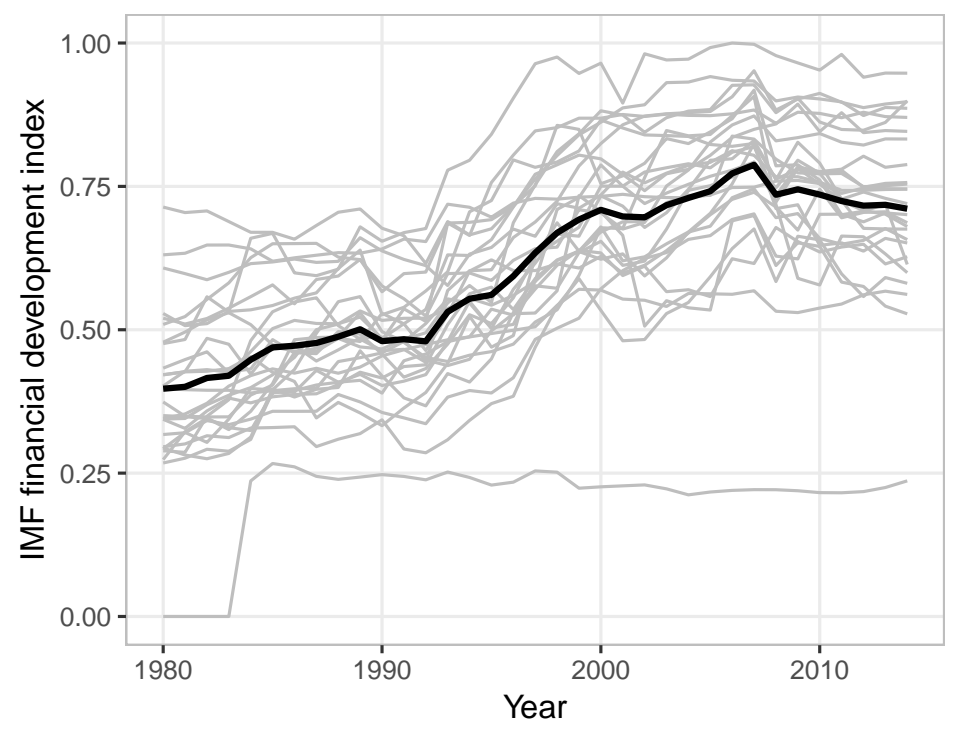

Notes: The figure shows the index for all advanced economies (gray lines) and the average (black line). For details on the index see Svirydzenka (2016). 
Figure A.4: Sectoral Credit Flows in OECD Countries, Averages for 1994-2005

(a) Business Credit (\% of GDP)

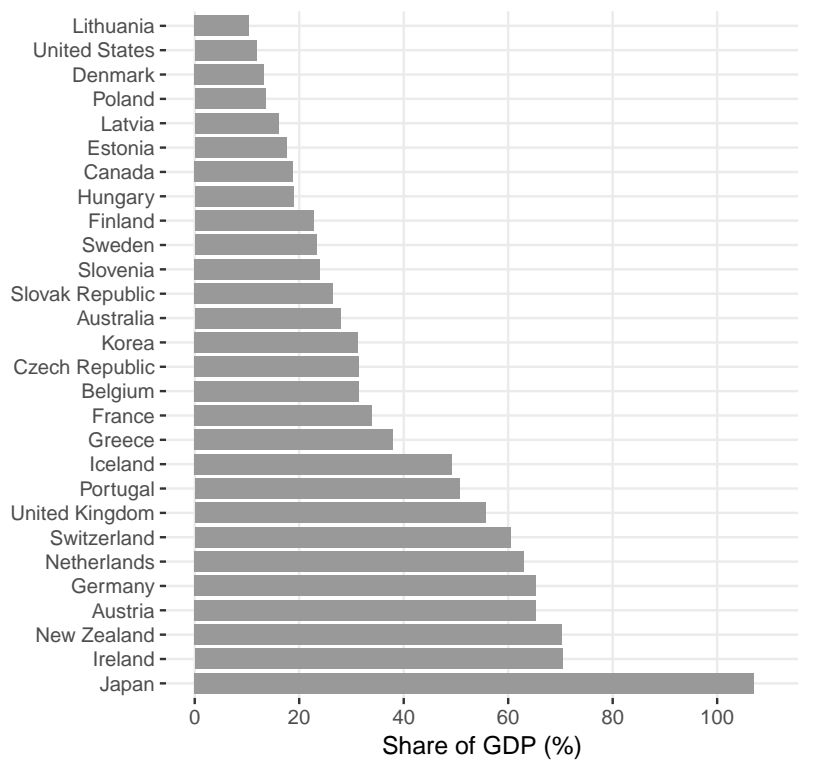

(b) Distribution of Bank Credit by Sector

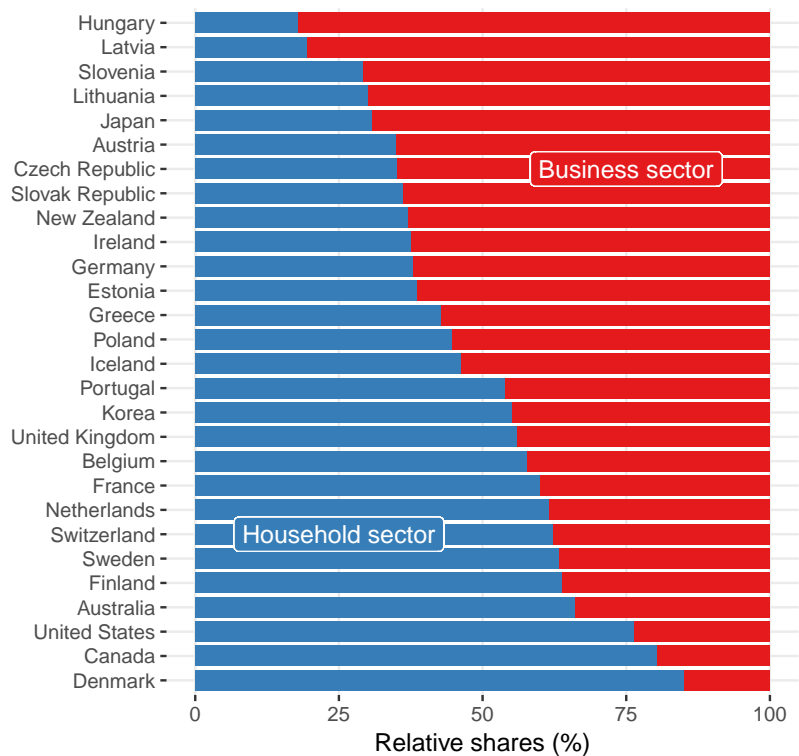

Notes: Panel (a) shows total credit to the business sector as a share of GDP. Panel (b) shows the relative shares of bank credit that go to the household sector or the business sector. Source: (Beck et al. 2012, Table 1). 


\section{A.3 Further Details and Regression Results for LITS Data}

Figure A.5: Use of Different Coping Mechanisms in Light of Economic Shocks
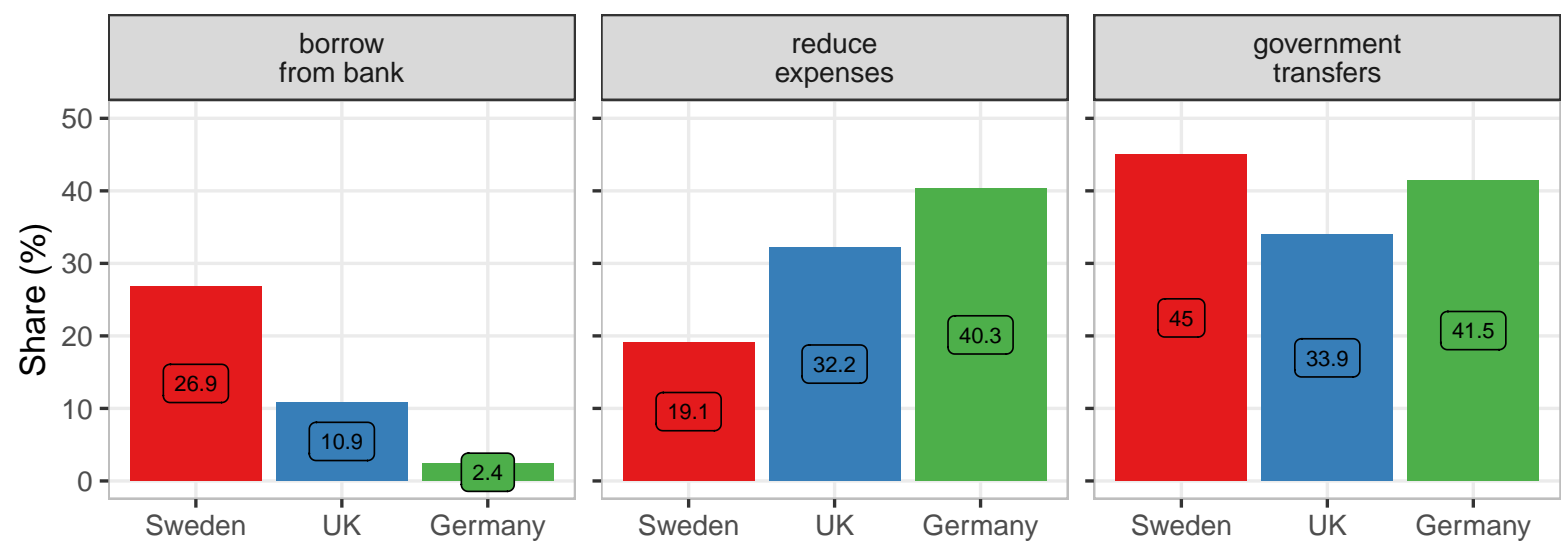

Notes: Questions: "In the past two years, have you or anyone else in your household had to take any of the following measures as the result of a decline in income or other economic difficulties? In the past two years, have you or any member of your household tried to borrow money from anyone? (e.g. a friend, other person or institution)". Respondents could select multiple coping mechanisms. Source: LITS Wave II 2010. 
Table A.3: Coping Mechanisms by Country

\begin{tabular}{|c|c|c|c|}
\hline & \multicolumn{3}{|c|}{ Dependent variable: } \\
\hline & $\begin{array}{c}\text { reduce expenses } \\
\text { (1) }\end{array}$ & $\begin{array}{l}\text { borrow from bank } \\
(2)\end{array}$ & $\begin{array}{c}\text { government transfers } \\
\text { (3) }\end{array}$ \\
\hline Homeowner & $\begin{array}{l}-0.25^{* * *} \\
(0.07)\end{array}$ & $\begin{array}{c}0.02 \\
(0.11)\end{array}$ & $\begin{array}{l}-0.56^{* * *} \\
(0.08)\end{array}$ \\
\hline Income (deciles) & $\begin{array}{l}-0.23^{* * *} \\
(0.02)\end{array}$ & $\begin{array}{r}-0.04 \\
(0.03)\end{array}$ & $\begin{array}{c}-0.35^{* * *} \\
(0.03)\end{array}$ \\
\hline Employed & $\begin{array}{c}0.09 \\
(0.08)\end{array}$ & $\begin{array}{l}0.25^{* *} \\
(0.12)\end{array}$ & $\begin{array}{l}-0.34^{* * *} \\
(0.09)\end{array}$ \\
\hline Education level & $\begin{array}{l}-0.06^{* * *} \\
(0.02)\end{array}$ & $\begin{array}{l}0.06^{* *} \\
(0.03)\end{array}$ & $\begin{array}{c}-0.01 \\
(0.03)\end{array}$ \\
\hline Married & $\begin{array}{c}0.10 \\
(0.07)\end{array}$ & $\begin{array}{c}0.08 \\
(0.10)\end{array}$ & $\begin{array}{r}-0.02 \\
(0.08)\end{array}$ \\
\hline Respondent male & $\begin{array}{c}-0.14^{* *} \\
(0.06)\end{array}$ & $\begin{array}{c}0.06 \\
(0.09)\end{array}$ & $\begin{array}{r}-0.03 \\
(0.08)\end{array}$ \\
\hline Age head 25-34 & $\begin{array}{c}-0.28 \\
(0.18)\end{array}$ & $\begin{array}{r}-0.20 \\
(0.24)\end{array}$ & $\begin{array}{r}-0.10 \\
(0.18)\end{array}$ \\
\hline Age head 25-34 & $\begin{array}{r}-0.12 \\
(0.18)\end{array}$ & $\begin{array}{c}0.04 \\
(0.24)\end{array}$ & $\begin{array}{r}-0.28 \\
(0.18)\end{array}$ \\
\hline Age head 35-44 & $\begin{array}{r}-0.11 \\
(0.17)\end{array}$ & $\begin{array}{r}-0.23 \\
(0.24)\end{array}$ & $\begin{array}{c}-0.44^{* *} \\
(0.18)\end{array}$ \\
\hline Age head 45-54 & $\begin{array}{c}-0.45^{* *} \\
(0.18)\end{array}$ & $\begin{array}{l}-0.69^{* * *} \\
(0.25)\end{array}$ & $\begin{array}{l}-1.11^{* * *} \\
(0.19)\end{array}$ \\
\hline Age head 55-64 & $\begin{array}{l}-1.10^{* * *} \\
(0.18)\end{array}$ & $\begin{array}{l}-1.24^{* * *} \\
(0.27)\end{array}$ & $\begin{array}{l}-2.32^{* * *} \\
(0.21)\end{array}$ \\
\hline Age head $65+$ & $\begin{array}{l}0.11^{* * *} \\
(0.04)\end{array}$ & $\begin{array}{c}0.11^{* *} \\
(0.05)\end{array}$ & $\begin{array}{l}0.25^{* * *} \\
(0.04)\end{array}$ \\
\hline Number of children in hh & $\begin{array}{l}2.03^{* * *} \\
(0.50)\end{array}$ & $\begin{array}{c}-2.40^{* * *} \\
(0.48)\end{array}$ & $\begin{array}{l}1.34^{* * *} \\
(0.31)\end{array}$ \\
\hline $\begin{array}{l}\sigma_{F R} \\
\sigma_{D E} \\
\sigma_{I T} \\
\sigma_{S E} \\
\sigma_{U K} \\
\end{array}$ & $\begin{array}{c}0.25 \\
-0.54 \\
1.85 \\
-1.12 \\
-0.44\end{array}$ & $\begin{array}{c}0.29 \\
-1.35 \\
-0.55 \\
1.10 \\
0.55\end{array}$ & $\begin{array}{c}0.11 \\
0.19 \\
-0.78 \\
0.66 \\
-0.17\end{array}$ \\
\hline $\begin{array}{l}\text { Observations } \\
\text { Log Likelihood } \\
\text { Akaike Inf. Crit. } \\
\text { Bayesian Inf. Crit. }\end{array}$ & $\begin{array}{c}5,445 \\
-3,116.92 \\
6,261.85 \\
6,354.28\end{array}$ & $\begin{array}{c}5,445 \\
-1,636.57 \\
3,301.15 \\
3,393.58\end{array}$ & $\begin{array}{c}5,445 \\
-2,227.55 \\
4,483.09 \\
4,575.53\end{array}$ \\
\hline
\end{tabular}

Note: Fixed effects from a generalized linear mixed-effects model with country random effects. Questions: "In the past two years [2008,2009], have you or anyone else in your household had to take any of the following measures as the result of a decline in income or other economic difficulties? In the past two years, have you or any member of your household tried to borrow money from anyone? (e.g. a friend, other person or institution)." The random effects are displayed in Figure $5 .{ }^{*} \mathrm{p}<0.1 ;{ }^{* *} \mathrm{p}<0.05 ;{ }^{* * *} \mathrm{p}<0.01$. 


\section{A.4 Full Regression Results}

Table A.4: The Effect of Unemployment Insurance Generosity on Household Debt by Credit Regime Permissiveness

\begin{tabular}{lcc}
\hline \hline & \multicolumn{2}{c}{ Dependent variable: } \\
\cline { 2 - 3 } & Total credit to households (\% GDP) & $(2)$ \\
\hline UI generosity & $0.103^{*}$ & -0.013 \\
& $(0.060)$ & $(0.061)$ \\
Financial development & $0.491^{* * *}$ & $0.408^{* * *}$ \\
& $(0.096)$ & $(0.101)$ \\
Capital account openness & & 0.033 \\
& & $(0.036)$ \\
Real GDP growth & & $-0.010^{* * *}$ \\
& & $(0.003)$ \\
Unemployment rate & & $-0.016^{* * *}$ \\
& & $(0.004)$ \\
Government deficit & & -0.003 \\
& & $(0.003)$ \\
Share service sector employment & & 0.244 \\
Gini & & $(0.444)$ \\
& & 0.002 \\
Government outlays & & $(0.003)$ \\
& & $0.007^{* * *}$ \\
UI generosity $\times$ Fin. development & $-0.508^{* * *}$ & $(0.003)$ \\
& $(0.123)$ & $-0.450^{* * *}$ \\
\hline DV mean & 0.557 & $(0.136)$ \\
Country fixed effects & $\checkmark$ & 0.557 \\
Year fixed effects & $\checkmark$ & $\checkmark$ \\
Observations & 534 & $\checkmark$ \\
Unique countries & 20 & 534 \\
$\mathrm{R}^{2}$ & 0.865 & 20 \\
Adjusted R ${ }^{2}$ & 0.850 & 0.889 \\
\hline \hline
\end{tabular}

Note: Results from fixed effect regression models. Bootstrapped standard errors are clustered at the country level and reported in parentheses. ${ }^{*} \mathrm{p}<0.1 ;{ }^{* *} \mathrm{p}<0.05 ;{ }^{* * *} \mathrm{p}<0.01$. 
Table A.5: Marginal Effects of Layoff and Absence Without Layoff on Unsecured Debt

\begin{tabular}{|c|c|c|c|c|}
\hline & \multicolumn{4}{|c|}{ Dependent variable: } \\
\hline & \multicolumn{4}{|c|}{ Total household unsecured debt (log) } \\
\hline & $(1)$ & $(2)$ & $(3)$ & $(4)$ \\
\hline Layoff & $\begin{array}{l}0.15^{* * *} \\
(0.05)\end{array}$ & $\begin{array}{l}0.20^{* *} \\
(0.08)\end{array}$ & & \\
\hline Absence without layoff & & & $\begin{array}{l}0.17^{* * *} \\
(0.06)\end{array}$ & $\begin{array}{c}0.05 \\
(0.10)\end{array}$ \\
\hline Income: 2 nd tertile & $\begin{array}{c}-0.25^{* * *} \\
(0.04)\end{array}$ & $\begin{array}{c}-0.24^{* * *} \\
(0.04)\end{array}$ & $\begin{array}{c}-0.25^{* * *} \\
(0.04)\end{array}$ & $\begin{array}{c}-0.26^{* * *} \\
(0.04)\end{array}$ \\
\hline Income: top tertile & $\begin{array}{l}0.14^{* * *} \\
(0.03)\end{array}$ & $\begin{array}{l}0.14^{* * *} \\
(0.03)\end{array}$ & $\begin{array}{l}0.16^{* * *} \\
(0.03)\end{array}$ & $\begin{array}{l}0.15^{* * *} \\
(0.03)\end{array}$ \\
\hline Education: some college & $\begin{array}{c}0.21^{*} \\
(0.11)\end{array}$ & $\begin{array}{c}0.21^{*} \\
(0.11)\end{array}$ & $\begin{array}{c}0.22^{*} \\
(0.11)\end{array}$ & $\begin{array}{l}0.22^{*} \\
(0.11)\end{array}$ \\
\hline Education: college & $\begin{array}{l}0.45^{* * *} \\
(0.16)\end{array}$ & $\begin{array}{l}0.45^{* * *} \\
(0.16)\end{array}$ & $\begin{array}{c}0.40^{* *} \\
(0.16)\end{array}$ & $\begin{array}{l}0.40^{* *} \\
(0.16)\end{array}$ \\
\hline Education: BA & $\begin{array}{l}0.55^{* * *} \\
(0.18)\end{array}$ & $\begin{array}{l}0.55^{* * *} \\
(0.18)\end{array}$ & $\begin{array}{l}0.62^{* * *} \\
(0.18)\end{array}$ & $\begin{array}{l}0.62^{* * *} \\
(0.18)\end{array}$ \\
\hline Education: MA & $\begin{array}{c}0.63^{* *} \\
(0.26)\end{array}$ & $\begin{array}{c}0.63^{* *} \\
(0.26)\end{array}$ & $\begin{array}{c}0.65^{* *} \\
(0.26)\end{array}$ & $\begin{array}{l}0.65^{* *} \\
(0.26)\end{array}$ \\
\hline Age & $\begin{array}{l}0.07 \\
(0.04)\end{array}$ & $\begin{array}{c}0.07 \\
(0.04)\end{array}$ & $\begin{array}{c}0.06 \\
(0.05)\end{array}$ & $\begin{array}{c}0.06 \\
(0.05)\end{array}$ \\
\hline Age square & $\begin{array}{c}-0.00 \\
(0.00)\end{array}$ & $\begin{array}{c}-0.00 \\
(0.00)\end{array}$ & $\begin{array}{c}-0.00 \\
(0.00)\end{array}$ & $\begin{array}{c}-0.00 \\
(0.00)\end{array}$ \\
\hline Number of children & $\begin{array}{c}0.02 \\
(0.03)\end{array}$ & $\begin{array}{c}0.02 \\
(0.03)\end{array}$ & $\begin{array}{c}0.01 \\
(0.03)\end{array}$ & $\begin{array}{c}0.01 \\
(0.03)\end{array}$ \\
\hline Married & $\begin{array}{l}0.87^{* * *} \\
(0.07)\end{array}$ & $\begin{array}{l}0.87^{* * *} \\
(0.07)\end{array}$ & $\begin{array}{l}0.90^{* * * *} \\
(0.08)\end{array}$ & $\begin{array}{l}0.90^{* * * *} \\
(0.08)\end{array}$ \\
\hline Single & $\begin{array}{c}-0.57^{* * *} \\
(0.08)\end{array}$ & $\begin{array}{c}-0.57^{* * *} \\
(0.08)\end{array}$ & $\begin{array}{c}-0.55^{* * *} \\
(0.08)\end{array}$ & $\begin{array}{c}-0.55^{* * *} \\
(0.08)\end{array}$ \\
\hline Renter & $\begin{array}{c}-0.11^{* *} \\
(0.06)\end{array}$ & $\begin{array}{c}-0.11^{* *} \\
(0.06)\end{array}$ & $\begin{array}{c}-0.12^{* *} \\
(0.06)\end{array}$ & $\begin{array}{c}-0.12^{* *} \\
(0.06)\end{array}$ \\
\hline White & $\begin{array}{c}-0.00 \\
(0.66)\end{array}$ & $\begin{array}{c}0.00 \\
(0.66)\end{array}$ & $\begin{array}{c}-0.19 \\
(0.74)\end{array}$ & $\begin{array}{c}-0.18 \\
(0.74)\end{array}$ \\
\hline Asian & $\begin{array}{c}0.79 \\
(0.90)\end{array}$ & $\begin{array}{c}0.79 \\
(0.90)\end{array}$ & $\begin{array}{c}0.98 \\
(0.98)\end{array}$ & $\begin{array}{c}0.98 \\
(0.98)\end{array}$ \\
\hline Black & $\begin{array}{c}0.68 \\
(0.82)\end{array}$ & $\begin{array}{c}0.68 \\
(0.82)\end{array}$ & $\begin{array}{c}0.72 \\
(0.89)\end{array}$ & $\begin{array}{c}0.73 \\
(0.89)\end{array}$ \\
\hline Savings (log) & $\begin{array}{l}0.13^{* * *} \\
(0.00)\end{array}$ & $\begin{array}{l}0.13^{* * *} \\
(0.00)\end{array}$ & $\begin{array}{l}0.13^{* * *} \\
(0.00)\end{array}$ & $\begin{array}{l}0.13^{* * *} \\
(0.00)\end{array}$ \\
\hline Mortgage interest rate & $\begin{array}{l}0.01^{* * *} \\
(0.00)\end{array}$ & $\begin{array}{l}0.01^{* * *} \\
(0.00)\end{array}$ & $\begin{array}{l}0.01^{* * *} \\
(0.00)\end{array}$ & $\begin{array}{l}0.01^{* * *} \\
(0.00)\end{array}$ \\
\hline Savings constrained & $\begin{array}{l}0.29^{* * *} \\
(0.03)\end{array}$ & $\begin{array}{l}0.29^{* * *} \\
(0.03)\end{array}$ & $\begin{array}{l}0.29^{* * *} \\
(0.03)\end{array}$ & $\begin{array}{l}0.29^{* * *} \\
(0.03)\end{array}$ \\
\hline Layoff $\times$ Income: 2 nd tertile & & $\begin{array}{c}-0.07 \\
(0.10)\end{array}$ & & \\
\hline Layoff $\times$ Income: top tertile & & $\begin{array}{c}-0.05 \\
(0.12)\end{array}$ & & \\
\hline Absence without layoff $\times 2$ nd income tertile & & & & $\begin{array}{r}0.26^{*} \\
(0.14)\end{array}$ \\
\hline Absence without layoff $\times$ top income tertile & & & & $\begin{array}{c}0.11 \\
(0.14)\end{array}$ \\
\hline DV mean & 6.07 & 6.07 & 6.11 & 6.11 \\
\hline Households fixed effects & $\checkmark$ & $\checkmark$ & $\checkmark$ & $\checkmark$ \\
\hline Year fixed effects & $\checkmark$ & $\checkmark$ & $\checkmark$ & $\checkmark$ \\
\hline Observations & 362,248 & 362,248 & 348,513 & 348,513 \\
\hline $\mathrm{R}^{2}$ & 0.73 & 0.73 & 0.73 & 0.73 \\
\hline Adjusted $\mathrm{R}^{2}$ & 0.45 & 0.45 & 0.45 & 0.45 \\
\hline
\end{tabular}

Note: Results from fixed effect regression models. The omitted baselines are full-time employed individuals. Robust standard errors in parentheses. ${ }^{*} \mathrm{p}<0.1 ;{ }^{* *} \mathrm{p}<0.05 ;{ }^{* * *} \mathrm{p}<0.01$. 


\section{A.5 Supplemental References}

Beck, Thorsten, Berrak Büyükkarabacak, Felix K. Rioja and Neven T. Valev. 2012. "Who Gets the Credit? And Does It Matter? Household vs. Firm Lending Across Countries." The B.E. Journal of Macroeconomics 12(1).

Petersson, Flemming, Mikkel Baadsgaard and Lau Caspar Thygesen. 2011. "Danish Registers on Personal Labour Market Affiliation." Scandinavian Journal of Public Health 39(7 Suppl):95-98.

Svirydzenka, Katsiaryna. 2016. "Introducing a New Broad-Based Index of Financial Development." IMF Working Paper WP/16/5. 